\title{
Signatures of Restoration and Management Changes in the Water Quality of a Central California Estuary
}

\author{
Alison K. Gee • Kerstin Wasson • Susan L. Shaw • \\ John Haskins
}

Received: 29 June 2009 /Revised: 9 August 2009/Accepted: 6 February 2010 / Published online: 20 April 2010

(C) The Author(s) 2010. This article is published with open access at Springerlink.com

\begin{abstract}
Coastal managers and policy-makers are concerned with tracking improvements to water quality linked to management changes. Long-term water quality data acquired from two wetland areas in the upper reaches of the Elkhorn Slough estuary in central California were analyzed for signatures of land restoration or water control structure management. Post-restoration averaged $\mathrm{NO}_{3}, \mathrm{NH}_{3}$, and $\mathrm{PO}_{4}$ concentrations were $50-70 \%$ less than before-restoration concentrations. Assessment of watershed-scale effects revealed that proximity of restoration to sampling locations had almost as strong an effect on water quality as the percentage of land restored relative to watershed size. Results also suggest that restoration of even $1 \%$ of an agriculturally intensive watershed such as that of the Elkhorn Slough may result in improvements to water quality. Finally, results indicate that tide gate function can dominate water quality in managed wetlands and must be carefully tracked and managed in the context of estuarine conservation targets.
\end{abstract}

Keywords Restoration · Water quality · Nutrient loading · Tide gate management $\cdot$ Eutrophication

A. K. Gee $(\bowtie) \cdot$ K. Wasson $\cdot$ S. L. Shaw $\cdot$ J. Haskins Elkhorn Slough National Estuarine Research Reserve, 1700 Elkhorn Road,

Watsonville, CA 95076, USA

e-mail: agee108@gmail.com

A. K. Gee

Institute of Marine Sciences,

University of California at Santa Cruz,

Santa Cruz, CA 95064, USA

\section{K. Wasson}

Department of Ecology and Evolutionary Biology,

University of California at Santa Cruz,

Santa Cruz, CA 95064, USA

\section{Introduction}

Recent global demographic studies have found as much as $78 \%$ of the world population to live within $50 \mathrm{~km}$ of sea level, with population densities expected to intensify in urban centers located along coast lines worldwide (Small and Nicholls 2003; Cohen 2003). Following release of the historic WHO demographic study in 1968 predicting that $80 \%$ of the world's human population would live within $20 \mathrm{~km}$ of the coast by the beginning of the twenty-first century, concern dramatically increased over estuarine health. This is reflected in a multitude of studies published around the world in the last four decades focusing on declining estuarine water quality and increasing contaminants from urban, industrial, and agricultural sources (Cohen et al. 1997). Researchers in estuaries surrounded by urban centers such as the San Francisco Bay, the urban estuary (Conomos 1979), have developed robust and detailed monitoring programs to focus on a suite of point and nonpoint source industrial and urban pollutants to evaluate water quality and associated impacts to humans and wild life, e.g., San Francisco Estuary Institute (SFEI) Regional Monitoring Program (RMP) for Trace Substances (Flegal 2000). The nearby Elkhorn Slough estuary south of San Francisco Bay might more appropriately be called the agricultural estuary, since $24 \%$ of its watershed is in agricultural cultivation. Runoff into the slough from agricultural activities has grown each decade following the upsurge of intensive agriculture along the Central California coast post-World War II (Caffrey et al. 2002a). In the 1970s, Elkhorn Slough nutrient concentrations were lower than those found in South San Francisco Bay and were similar to those measured in neighboring Tomales Bay, CA, USA (Smith and Hollibaugh 1997). Two decades later, ammonium and nitrate concentrations in the slough 
were generally an order of magnitude higher than those measured in South San Francisco Bay, where the dominant source of nutrients is from wastewater treatment plants (Nichols et al. 1986; Hager and Schemel 1996). The nitrate concentration range currently measured in the Elkhorn Slough monthly water quality monitoring program is three orders of magnitude higher than those measured in Tomales Bay in the late 1990s (Caffrey et al. 2007). Nitrate concentrations measured in the main channel of the Elkhorn Slough at Kirby Park from 2006 to 2007 are roughly double the concentrations measured in the same years in South San Francisco Bay (data comparison made using the SFEI RMP web query tool at http://eis.sfei.org/wqt and detailed in SFEI 2008). Peak and median phosphate and ammonium concentrations in the slough are also high compared to many other estuaries worldwide (Caffrey et al. 1997).

While eutrophication has been occurring in freshwater systems for centuries, increasing eutrophication and even hypoxia resulting from an excess of nutrient inputs has been observed in many estuarine and coastal systems in the past three decades (Kemp and Boynton 1984; Nixon 1995; Beck and Bruland 2000; Beck et al. 2001; Paerl 2009). Eutrophication is now regarded as one of the greatest threats to coastal ecosystem health worldwide, due to nutrient inputs to coastal waters being many times higher than historic concentrations (NRC 2000). Coastal eutrophication has been reported to be widespread in national surveys within the USA, where $65 \%$ of all assessed estuarine systems were classified as moderate to high overall eutrophic status (Bricker et al. 1999, 2008). Similar widespread concern over nutrient loading to coastal waters has been documented globally with future projections of increased eutrophic status worldwide in the next several decades (Smetacek et al. 1991; Gray 1992; Heip 1995; Jorgensen and Richardson 1996; Richardson 1996; Nixon 1998; Vidal et al. 1999; Cloern 2001; Howarth et al. 2002). Common primary symptoms of enriched nutrient concentrations leading to eutrophication in estuarine systems include an increase in chlorophyll $a$, macroalgae, submerged aquatic vegetation, and nuisance/ toxic algal blooms coincident with decreased dissolved oxygen concentrations (Boesch et al. 2001; Diaz and Rosenberg 2008; Bricker et al. 2008). Conceptual models of eutrophication processes in coastal systems now include a dynamic understanding that nutrient enrichment can also force selective changes in biological diversity and biogeochemical processes throughout coastal food webs that vary in their expression with tidal amplitude, water depth, water stratification, and water residence times among other parameters (Monbet 1992; Valiela et al. 1997, 2000; Cloern 1999, 2001; Oberg 2005; McGlathery et al. 2007; Cloern and Jassby 2008; Duarte et al. 2009).

Scientifically robust restoration efforts in coastal and marine environments are currently being undertaken (e.g.,
Boesch 2006; Perry 2008; Thebault et al. 2008) but have tended to lag behind freshwater restoration projects, due in part to the more open nature of marine environments (Simenstad et al. 2006). While there has been much written striving to clarify the use of terms like mitigation, restoration, and remediation commonly used for freshwater restoration efforts, studies that actually track the return of estuarine systems to predisturbance conditions in response to restoration or management practices are rare (Elliot et al. 2007; Duarte et al. 2009). It has been argued by the National Research Council that the term restoration should only be used for those activities directed at rebuilding an entire ecosystem, including both its structure and function (NRC 1992). However, many coastal aquatic systems are so intensely altered, with shared ecological and socioeconomic uses that restoration goals in this fullest sense of the word are impossible, or perhaps not even desirable. Stewards of coastal environments are often faced with the dilemma of designing programs to rehabilitate and manage disturbed aquatic systems without the long-term data or preplanned scientific experiments spanning the disturbance times that document the measurable goal conditions they are aiming toward restoration efforts (Ruiz-Jaen and Aide 2005; Van Cleve et al. 2006).

The monthly volunteer-based water quality monitoring program at the Elkhorn Slough provides a unique opportunity to investigate the impact of coincident restoration and tide gate management changes on water quality over nearly two decades. Often monitoring data are maintained in a general sense and not assessed with respect to impacts from specific restoration and management projects (Ruiz-Jaen and Aide 2005). This monitoring program was launched in 1988 to establish a baseline of data to track physicochemical and nutrient water qualities over time. There are 26 water quality monitoring stations sampled by this program; this study considers water quality data from a subset of six of those stations (Fig. 1). Several years after this program started, a number of restoration projects were undertaken in the late 1990s and early 2000s in the Slough watershed, involving collaboration between the Elkhorn Slough Foundation, The Nature Conservancy, the Natural Resources Conservation Service, and the Resource Conservation District. Restoration involved pulling row crops (primarily strawberries) back $100 \mathrm{ft}$ from the high tide mark and planting previously cultivated land with native species (primarily bunchgrasses) and/or low erosion crops such as rosemary that require less tillage and fertilization (Fig. 2; Silberstein et al. 1997a, b; Rein 1999; Rein et al. 2007). This study aims to elucidate signatures of restoration in the water quality data collected pre- and postrestoration efforts, focusing on two case studies in the upper Elkhorn Slough where monitoring stations were placed to track changes in the managed wetlands of these subwatersheds. Major tide 


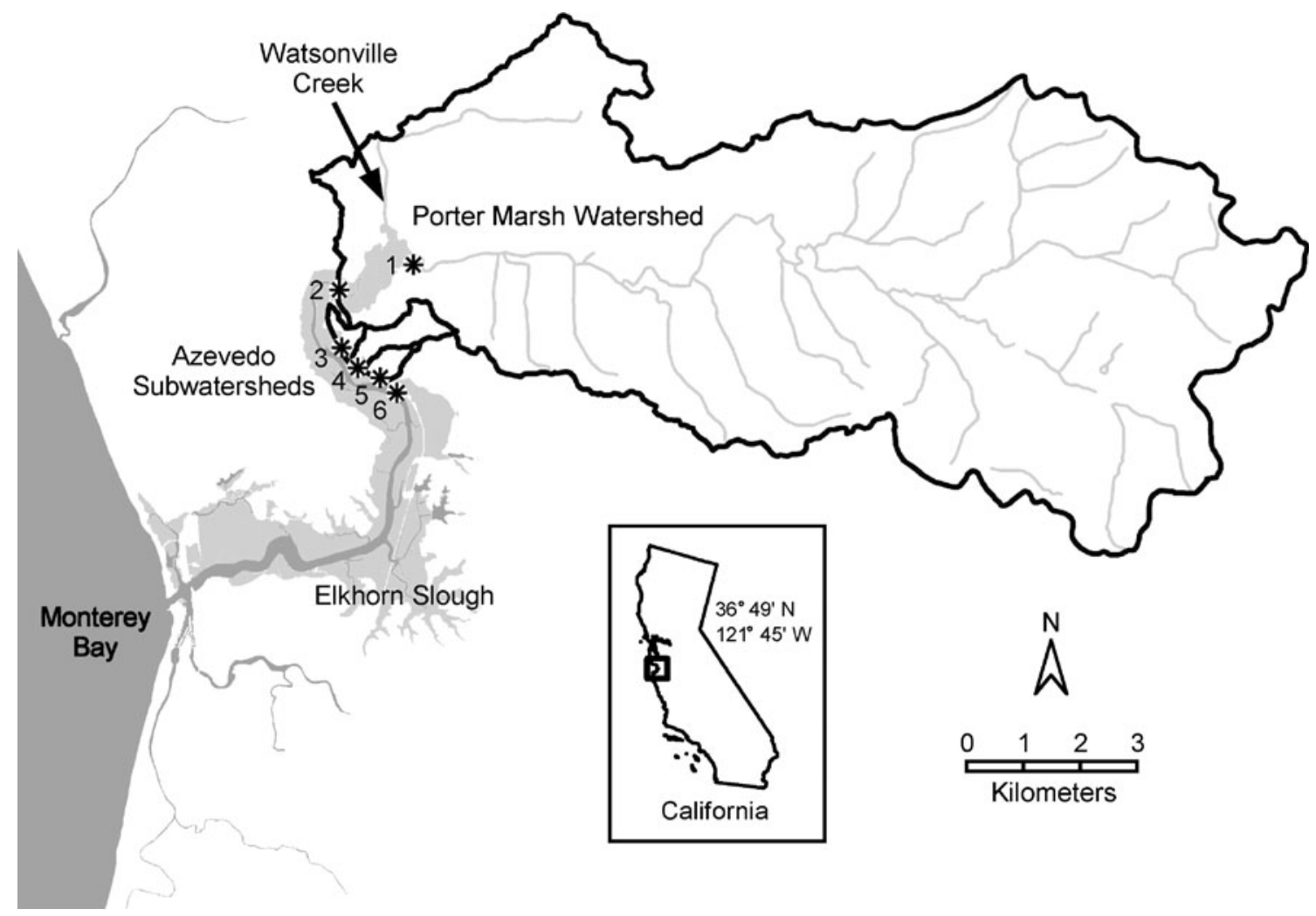

Fig. 1 Map of the six Elkhorn Slough volunteer water quality monitoring station locations considered in the two case studies presented here. 1 Carneros Creek (main freshwater source to slough), 2 Hudsons Landing, 3 Azevedo Pond North, 4 Azevedo Pond Central, 5 Azevedo Pond South, 6 Kirby Park (control station in main channel). The Porter Marsh tide gates are located at station 2. Also shown are the relative sizes of the Azevedo subwatersheds that drain into each respective pond

gate repairs were also completed in late 1995 at Hudsons Landing, 6 years prior to restoration implementation in the Porter Marsh complex, allowing signatures of water control structure management in the water quality data to also be investigated. With an estuary as diverse in its microenvironments as the Elkhorn Slough, inhabited by a wide spectrum of estuarine life responding to water quality in complex and different ways (Ritter et al. 2008), maintenance of longterm water quality monitoring becomes increasingly important, especially in light of the coastal environmental crises occurring on a global scale today (Boesch 2006).

\section{Materials and Methods}

\section{Study Area}

The Elkhorn Slough is a small estuary (area $3.25 \mathrm{~km}^{2}$ ) that drains into the Monterey Bay in Central California ( $36^{\circ} 48^{\prime}$ $\mathrm{N}, 121^{\circ} 47^{\prime} \mathrm{W}$; Fig. 1). It is comprised of a network of tidal wetlands and estuarine habitats that range from predominantly fresh water to predominantly marine influenced areas. and the much larger Porter Marsh watershed that drains into Carneros Creek and Hudsons Landing. The Watsonville Creek is an ephemeral secondary freshwater source to stations $2-6$, down gradient from the Carneros Creek monitoring station 1. Elkhorn Slough water and wetland are indicated in gray, draining into Monterey Bay. Note that an expanded view of the stations 3-6 locations is presented in Fig. 3

The average depth of the Slough is $2.5 \mathrm{~m}$, with a main channel average depth of $6.5 \mathrm{~m}$. The major fresh water source to the head of the estuary is the Carneros Creek, which is seasonal and has a flow range of $0-3.8 \mathrm{~m}^{3} \mathrm{~s}^{-1}$, depending on rainfall (Caffrey et al. 2007). The Watsonville Creek is a secondary ephemeral stream that also supplies freshwater to the upper reaches of the slough below the Carneros Creek monitoring station (Fig. 1). While seasonal flow from Carneros Creek is vital to maintaining freshwater marshes in the upper reaches of the Elkhorn Slough, tidal exchange is the main water transport mechanism. In addition, suspended sediment supplies normally associated with riverine inputs appear to be declining in the Slough, leading to loss of surrounding marshland and possible channel deepening (Van Dyke and Wasson 2005). Tides are mixed semidiurnal, with two highs and two low tides of unequal height that propagate into the different areas of the Slough to varying extents and with various lag times. The mean tidal range along the channel is $1.7 \mathrm{~m}$ (Largier et al. 1997). However, seawater from Monterey Bay can extend as far as $6 \mathrm{~km}$ into Elkhorn Slough on a high tide, past Kirby Park (Fig. 1; Breaker and Broenkow 1994). Between 50\% and 

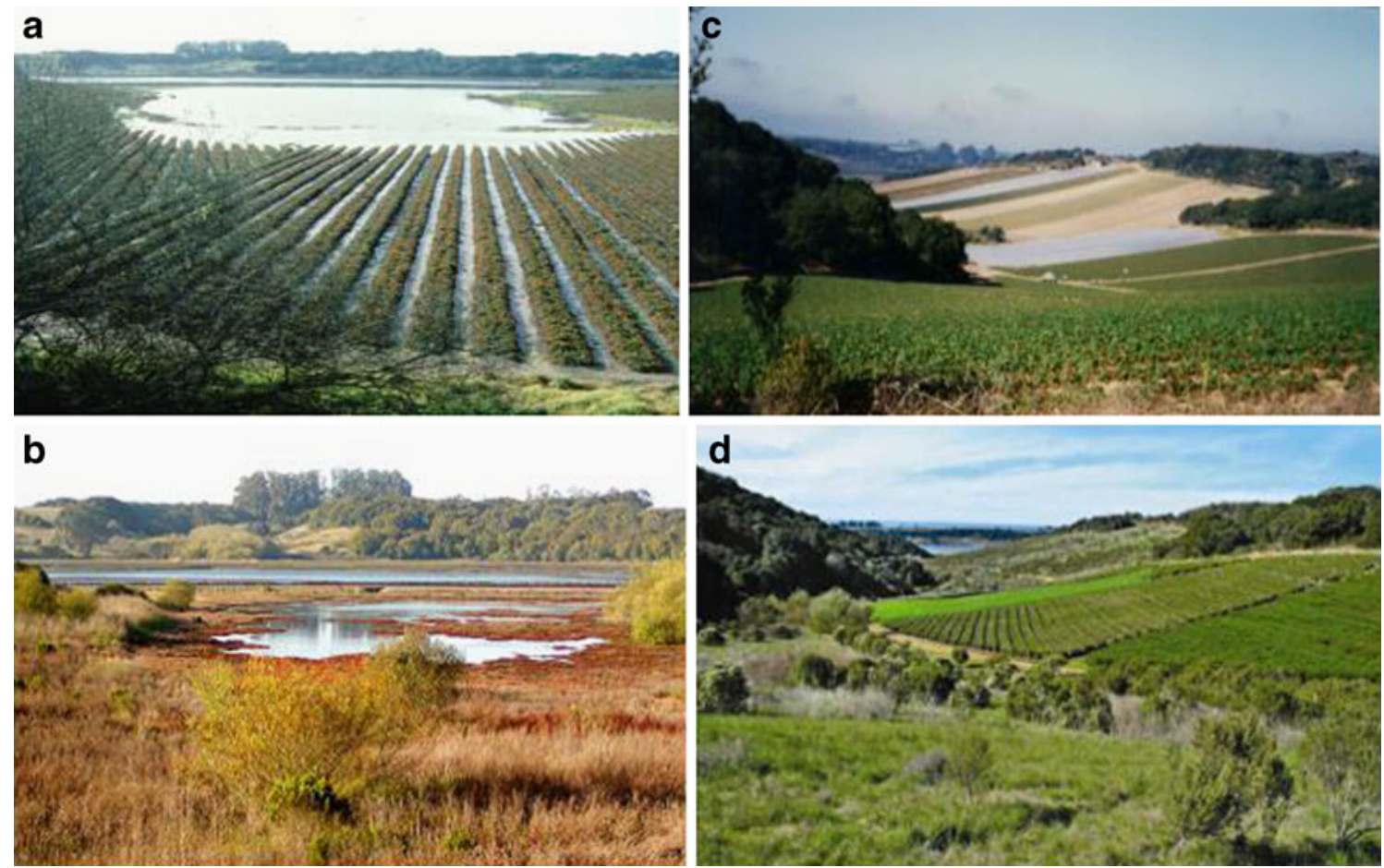

Fig. 2 Photographs of Azevedo Pond Central before and after restoration. Photos a (before) and b (after) are of the lower subwatershed while photos $\mathbf{c}$ (before) and $\mathbf{d}$ (after) are of the upper subwatershed for this pond. Restoration was complete in 1997. Photo

$75 \%$ of the volume of the Slough is exchanged with each tidal cycle (Wong 1989; Malzone 1999). Thus, marine influences are strong in the Slough; it is predominantly a saltwater estuary with a strong seasonal component. All portions of the Elkhorn Slough at or below the mean high tide mark lie within the Monterey Bay National Marine Sanctuary, designated as a national marine sanctuary in 1992. The Elkhorn Slough watershed is 18,200 ha in size, and 567 ha of surrounding marshland within this watershed comprises the Elkhorn Slough National Estuarine Research Reserve (ESNERR), designated as a national estuarine sanctuary in 1979 (Fig. 1).

Elkhorn Slough is a modified estuary, with a complex history of anthropogenic and natural changes to wetland distributions and hydrography. Details of the history of Elkhorn Slough and its anthropogenic disturbances can be found in Caffrey et al. (2002a) and Van Dyke and Wasson (2005). Pertinent to this study, the Southern Pacific Railway installed a track in 1872 east of the main channel that created an elevation gradient between the main channel and the Azevedo Ponds and adjacent wetlands. Tidal exchange only happens between the ponds and the channel through restricted culverts located below the railway, when the tide height at Moss Landing Harbor exceeds approximately $1.2 \mathrm{~m}$. The first case study considered here includes all three of these Azevedo Ponds, which are located in this

a was taken during winter at a high tidal stage while $\mathbf{b}$ was taken during spring at a midtidal stage. Note the change in cultivated crops pulled back from the water's edge and the creation of buffer strips comprised of native species

restricted area east of the railway tracks, each with their own subwatersheds that range in size from 30 to 83 ha (Fig. 1). These are managed wetlands, with tidal exchange regulated through water control structures to protect adjacent farm fields from tidal inundation. Azevedo Pond North (APN) is the largest pond ( $4.2 \mathrm{ha})$ and has two culverts that allow tidal exchange. The culvert at the southern end of APN broke open in 1997 and had remained this way, allowing substantially more tidal flushing from 1997 to the present than was originally intended. The maximum daily tidal range at APN is about $100 \mathrm{~cm}$, the depth at low tide is $<1 \mathrm{~m}$, and it experiences tidal exchange with every high tide (twice daily). Azevedo Pond Central (APC) and South (APS) have extremely limited tidal exchange (maximum daily tidal range of $<2 \mathrm{~cm}$ ) through narrow culverts, with a depth of $<0.5 \mathrm{~m}$. While these two smaller ponds do tend to experience a trickle of tidal exchange on a daily basis, it is important to note that the exchange is not enough to change the height of the water level over the course of a typical tidal cycle. Both APC (2.4 ha; Fig. 2) and APS (1.1 ha) periodically dry up during drought years.

The second case study focuses on the Porter Marsh Complex at the head of the Elkhorn Slough. The Porter Marsh watershed is three orders of magnitude larger than the subwatersheds draining into the Azevedo Ponds (Fig. 1). The Carneros Creek (CC) station is primarily freshwater and is $4,970 \mathrm{~m}$ (measured up the thalweg) from 
Kirby Park (Fig. 1). Carneros Creek water flows down into the main channel of the Slough via tide gates at Hudsons Landing that were designed to let freshwater flow south but block marine waters from flowing north into the freshwater environments of the Slough. The tide gates were installed after creation of the Moss Landing Harbor to prevent tidal flooding of adjacent agricultural lands while allowing for drainage of the Carneros basin. This former brackish estuarine habitat was thus managed as a freshwater impoundment. These gates sustained major earthquake damage in 1989, allowing for muted tidal exchange into the wetland. The tide gates were repaired in late 1995, returning the wetland to a freshwater impoundment with virtually no tidal exchange other than minor leakage at the gates. The other two water quality monitoring stations within Porter Marsh are on either side of these tide gates at Hudsons Landing (Hudsons Landing east (HLE) of the tide gates and Hudsons Landing west (HLW) of the tide gates and predominantly marine influenced). These two stations are approximately 3,300 $\mathrm{m}$ (measured up the thalweg) from Kirby Park. Residence times in this upper region of the Slough range from 50 days during the dry season to 1 day during the rainy season (Largier et al. 1997; Caffrey et al. 2007). Mobilization of nutrients like nitrate tends to be the highest in response to precipitation and runoff processes during the winter, when residence times are quite short (Correll et al. 1992; Chapin et al. 2004). There is an additional ephemeral freshwater supply from Watsonville Creek that feeds into the Slough above the Hudsons Landing stations but below the Carneros Creek station that has been noted to carry high concentrations of nitrate and phosphate during the rainy season (M. Los Huertos, personal communication).

The water monitoring station Kirby Park is used as a control site in both case studies presented here and is an average of $1,170 \mathrm{~m}$ (measured down the thalweg of the Slough) from the three Azevedo Ponds in the main channel of Elkhorn Slough (Fig. 1). Kirby Park was chosen as the "control" because it was not subject to any of the management effects investigated here. In addition, the Slough tidal prism is on the order of 13.1 million cubic meters (Malzone 1999). While the Azevedo Ponds have either muted (APN) or minimal (APC and APS) tidal exchange with the main channel in the vicinity of Kirby Park, their volume is trivial compared to the exchange of water passing thru the Slough main channel at this location. Any forcing due to weather will be similarly experienced and integrated in the water quality data from Kirby Park.

\section{Watershed and Restoration Acreage Calculations}

The goal of the geographic information system (GIS) analyses was to characterize the scale and spatial layout of restoration for each case study within the context of subwatershed size, pertinent to interpretations of the changing water quality seen over time. GIS analyses of aerial photographs from 1990 and 2000 were performed to assess the size of subwatersheds draining into each of the Azevedo Ponds, as well as to estimate the acreage of land under cultivation in those years (Table 1). The difference between cultivated acreage observed in these 2 years was identified in GIS and used to estimate the restored acreage (acreage taken out of commercial agricultural production) in each Azevedo subwatershed (areas outlined in red within each subwatershed in Fig. 3). Documentation of the restoration projects by Elkhorn Slough Foundation indicates that restoration efforts impacting the Azevedo Ponds were complete by 1997 (Silberstein et al. 1997a). To our knowledge, the restoration projects considered here are the only ones undertaken in these subwatersheds in these years. The distances to the restored fields in each watershed from the monitoring stations were also measured using GIS. Weighted average distances were then calculated based on the size of each restored parcel of land. These data are tabulated in Table 1, along with relevant historical information pertaining to each site, such as restoration completion dates, flood control management dates, or dates when culverts may have failed.

Similar GIS analyses were performed for the Porter Marsh sites CC and HLE (presented with Azevedo results in Fig. 3 and Table 1). For Porter Marsh, aerial photos were analyzed from the years 1990, 2000, and 2004, as the restoration project was ongoing over this time, complete by 2002 (M. Silberstein, personal communication). Note that the watershed for the whole of Elkhorn Slough is approximately $182 \mathrm{~km}^{2},(18,200 \mathrm{ha}$; Caffrey et al. 2002a). However, the acreage that represents the land draining into the specific water quality monitoring stations considered in this study were measured and presented (Table 1). The subwatershed draining into the Hudsons Landing East station is roughly half the size of the whole Slough watershed, while the area draining into Carneros Creek at the monitoring station used here is nested within the Porter Marsh watershed and is approximately nearly 1,500 ha smaller. The subwatersheds draining into each of the Azevedo Ponds are two orders of magnitude smaller still (Fig. 1; Table 1). For all GIS analyses, standard software was used (ArcView v.3.3). The US Geological Survey, Monterey County, and the Department of Fish and Game provided the georeferenced aerial photographs, one of which is included as a backing to Fig. 3.

\section{In Situ Physicochemical Water Quality Parameter Measurements}

The collection of water quality data commenced at the Elkhorn Slough in 1988 in response to a growing concern over elevated nutrient concentrations measured in the lower reaches of the Slough. The program has grown over the 


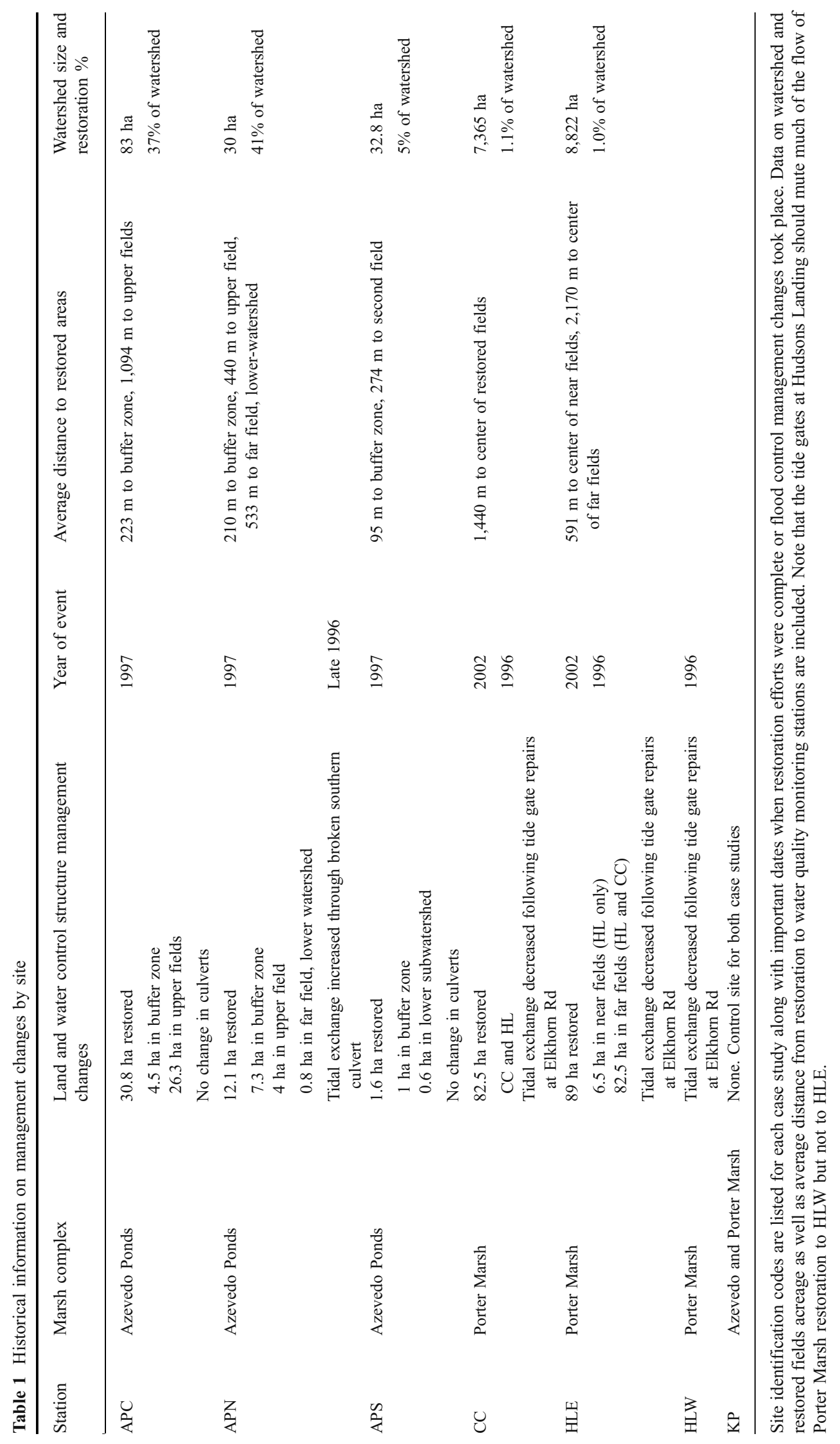


Fig. 3 GIS layers showing the area of land in agricultural cultivation based on aerial photographs from 1990 to 2004 . The areas enclosed in green are fields currently in cultivation and the areas enclosed in red are agricultural fields that were restored by the Elkhorn Slough Foundation in the years as tabulated in Table 1. Black lines indicate the three Azevedo subwatersheds and part of the larger Porter Marsh watershed boundary. The acreage taken out of cultivation is tabulated by subwatershed in Table 1. The numbered water quality monitoring stations are as in Fig. 1

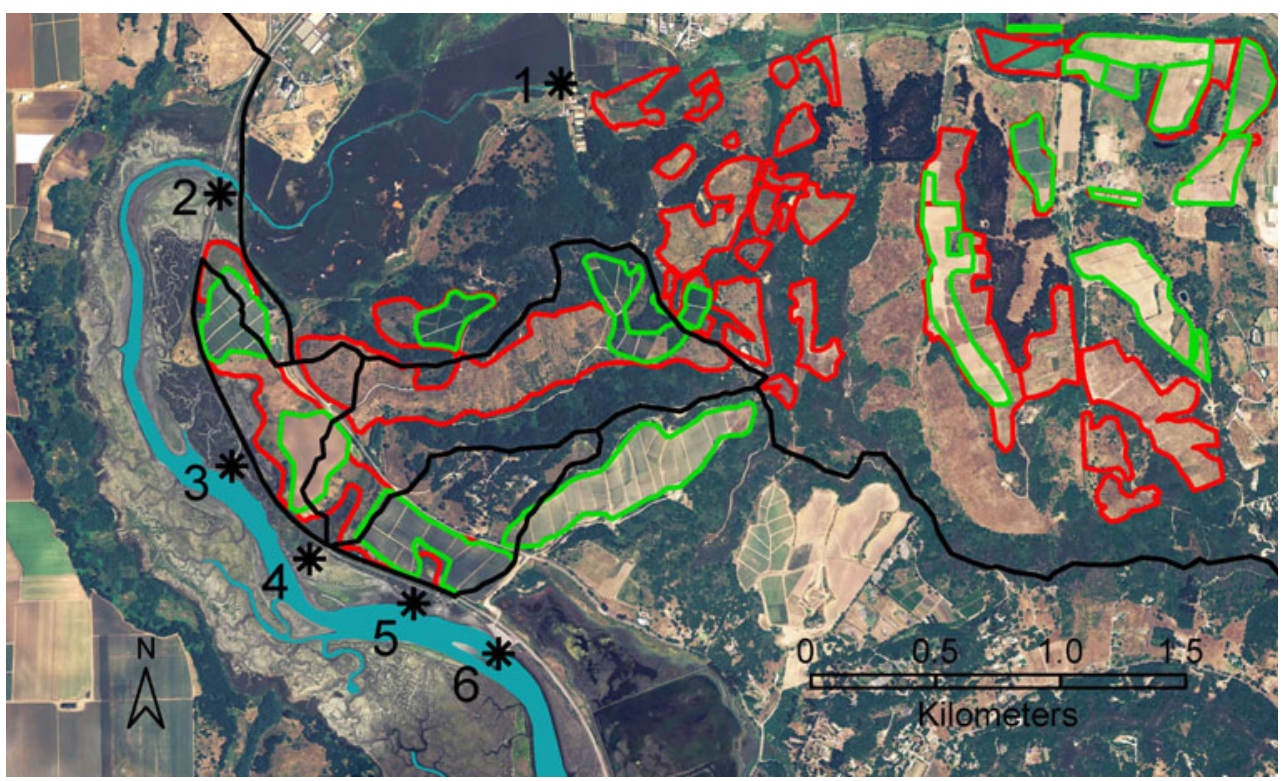

past two decades to include 26 stations and more sophisticated instrumentation to detect parameters of concern. The station locations considered in this study are a subset of the 26 stations monitored and are shown in Fig. 1. All data were acquired on a monthly basis. Both in situ data and grab samples for laboratory nutrient analysis were collected by a single dedicated volunteer (S. L. Shaw) over the past 18 years, providing consistency of sampling efforts, sites, and methods over this time period. From 1988 to 1994, conductivity, salinity, and temperature were measured in situ using a YSI 33 sonde. Dissolved oxygen was measured using a YSI 57 oxygen meter, $\mathrm{pH}$ was measured using an Orion $211 \mathrm{pH}$ meter, and turbidity was measured using a Moniteck 21 PE turbidity meter. In late 1994, the program switched to using a Solomat 803PS to measure temperature, $\mathrm{pH}$, salinity/conductivity, dissolved oxygen, and turbidity. From 2000 to present, a YSI 6000 multiparameter water quality sonde was used to measure conductivity (converted to salinity), temperature, $\mathrm{pH}$, dissolved oxygen, turbidity, and depth. Chlorophyll $a$ YSI 6025 and 6026 sensors were added to the in situ analyses in 2005, but this parameter could not be included in this study due to the lack of a long-term data record. All in situ measurements were made for surface water conditions at $0.5 \mathrm{~m}$ depth. All instruments used were calibrated according to their respective manual instructions. From 2000 to present, YSI sonde calibrations, data downloads, and processing followed protocols for the National Estuarine Research Reserve System Wide Monitoring Program: http://cdmo.baruch.sc.edu/data_dissemination.html\#NERR $\% 20$ Water\%20Quality\%20Data. In 2005, a Quality Assurance Project Plan (QAPP) was developed in conjunction with the Central Coast Regional Water Quality Control Board for the acquisition and evaluation of all monthly water quality data. In situ data acquisition regularly meets the precision and accuracy requirements of this QAPP for all parameters. These data are maintained and archived in the ESNERR volunteer monthly water quality monitoring program database and are available upon request. Rainfall data used in the interpretation of water quality data were retrieved from the Castroville weather station: http://wwwcimis.water.ca.gov/cimis/logon. do? forwardURL $=/$ frontMonthlyReport\&selTab $=$ data.

\section{Monthly Nutrient Analyses}

Water samples were collected each month at the same time, location, and depth as the in situ physicochemical readings. Water samples were collected into brown Nalgene bottles and stored on ice until they were transported to the laboratory for nutrient analyses. All water samples were filtered the same day they were collected, by carefully using a gentle vacuum (roughly $5 \mathrm{psi}$ ) so as to not rupture any plant cells in the samples. If nutrient analyses could not be performed within the first $48 \mathrm{~h}$ following sampling, filtered samples were frozen for later analyses. Field sample collection volunteers carried blanks of distilled water on ice treated identically to nutrient samples which are analyzed each month in order to assess potential contamination problems.

From 1989 to 1991, nutrient analyses were performed by the Monterey Bay Aquarium using standard wet chemical techniques for $\mathrm{NO}_{3}{ }^{-}, \mathrm{NH}_{4}{ }^{+}$, and $\mathrm{PO}_{4}{ }^{3-}$ (Apkem Series 300, Strickland and Parsons 1972). Starting in December 1991 to present, nutrients were analyzed at the Monterey County Consolidated Chemistry Laboratory (MCCCL) using US Environmental Protection Agency approved methods (APHA 2005). Currently, method EPS350.3 is used for $\mathrm{NH}_{3}-\mathrm{N}$, EPA300 is used for $\mathrm{NO}_{3}$, and SM4500PE is used for $\mathrm{PO}_{4}-\mathrm{P}$. The nitrate results from MCCCL are converted 
into $\mathrm{NO}_{3}-\mathrm{N}$ before being entered into the database. From November 1995 on, monthly sampling efforts have been coordinated with other ESNERR water quality monitoring efforts focused on four stations in the Slough that have 24-h continuous in situ monitoring of physicochemical parameters. Nutrient samples associated with that program are run at the Moss Landing Marine Laboratories (MLML). Periodically, all volunteer monthly samples are run at both MLML and MCCCL for interlaboratory calibration studies. Once a year, a three-way interlaboratory calibration is also performed, and samples are sent to MCCCL, MLML, and the University of California at Santa Cruz. Interlaboratory calibration studies indicate strong correlations between labs, with regression $R^{2}$ values generally over 0.95 . Prior to statistical analyses, detection limits for the different time periods were assessed for each analyte. For all nondetected sample results, one half of the detection limit corresponding to that sampling date and parameter was used instead of zero in the nutrient time series data prior to calculating annual averages. Current detection limits at the MCCCL laboratory for the three nutrients considered here are $0.01 \mathrm{mg} \mathrm{NO} / \mathrm{L}$, $0.05 \mathrm{mg} \mathrm{NH}_{3}-\mathrm{N}$, and $0.03 \mathrm{mg} \mathrm{PO}_{4}-\mathrm{P} / \mathrm{L}$. Examples of the raw time series nutrient data are presented for Azevedo Pond Central and the control station Kirby Park in Fig. 4.

\section{Statistical Analyses}

Before annual averages were calculated and statistical analyses were executed, monthly data in the database were inspected for errors. Any seemingly high outliers were first verified using field data sheets for physicochemical parameters or original lab reports for nutrients and corrected for inaccuracies. If inconsistencies were found between digital and hard copy data files, digital files were adjusted to match field and laboratory data sheets. Our nitrate monthly data from Kirby Park were also compared to an independent data set gathered by an auto-analyzer moored at Kirby Park, run by K. Johnson at the Monterey Bay Aquarium Research Institute (http://www.mbari.org/lobo/loboviz.htm; Johnson and Coletti 2002). The data sets match remarkably well, with the exception of four outliers identified in our data. These four measurements occurred at high salinities $(>27)$ and exceeded $300 \mu \mathrm{M} \mathrm{NO}$. They were excluded because they were extreme outliers in nitrate salinity plots where the data otherwise clustered neatly and we were doubtful of these high nitrate values at the high salinity range. These four data points represent less than $1 \%$ of the 17-year record of monthly data from Kirby Park considered in this study. The same salinity comparisons were made for the nitrate data collected at the other water quality stations. No outliers were identified or excluded in any of the ammonia or phosphate data, and no other outliers were excluded for any in situ measurements except for two turbidity readings exceeding
500 nephelometric turbidity units. Partial correlations between monthly samples were investigated for each parameter, with correlations observed between samples with a lag of 2 months (three consecutive samples). Above 4-month intervals, data points were not correlated for any parameter tested for. Given that independence of data points (no correlations) could not be ensured for data with less than a 4-month lag, annual averages were calculated for each parameter at each station and were used in all subsequent statistical and graphical analyses. All annually averaged data were normalized using $\log -10$ transformations prior to parametric tests, with the exception of salinity, $\mathrm{pH}$, and temperature.

The first null hypothesis tested was that there was no effect from restoration or tide gate repairs on any of the water quality parameters measured at our stations. To address this, two-way analysis of variance (ANOVA) using before vs. after controlled comparison investigations of control and impact sites (BACI) design was performed for each parameter (factors station and before vs. after treatment). Timelines for separating data were based on the histories of each site (Table 1). Statistical significance was assessed at a probability of $p<0.05$ and tabulated for each case study in Tables 2 and 3. BACI design was chosen for a more statistically rigorous interpretation of changes after treatment. Here, annual averages for each parameter measured at the control station Kirby Park (Slough main channel station) were subtracted from the annual averages calculated for each parameter at the other stations considered in this study, prior to running the statistics. By using BACI design and subtracting Kirby Park measurements appropriately, we were better able to isolate the effect of management changes on water quality, increase the power of our statistical tests, and gain more confidence in our results (Stewart-Oaten et al. 1986). In addition, there have been changes in the instruments used to measure the physicochemical parameters and in the laboratory nutrient analyses (as indicated in "Watershed and Restoration Acreage Calculations" and "In Situ Physicochemical Water Quality Parameter Measurements" sections) over the nearly two decades that the data were collected. Both of these problems are essentially minimized by BACI design because all samples for a given date were treated identically, so any possible shift due to methodology will be removed by subtracting Kirby annual averages. We did not find evidence for methodological biases over time in the data, but the BACI data analysis design resolves this concern.

For statistically significant results, concentration changes after treatment (restoration or tide gate repairs) were calculated as a percent of before treatment concentrations and are included with statistical results in Tables 2 and 3. In order to make concentration changes more evident to the reader, we chose to graphically present the data for 
Fig. 4 Time series nutrient and turbidity data from Azevedo Pond Central and Kirby Park (control station). Restoration was complete at APC in 1997, indicated by the vertical dashed lines

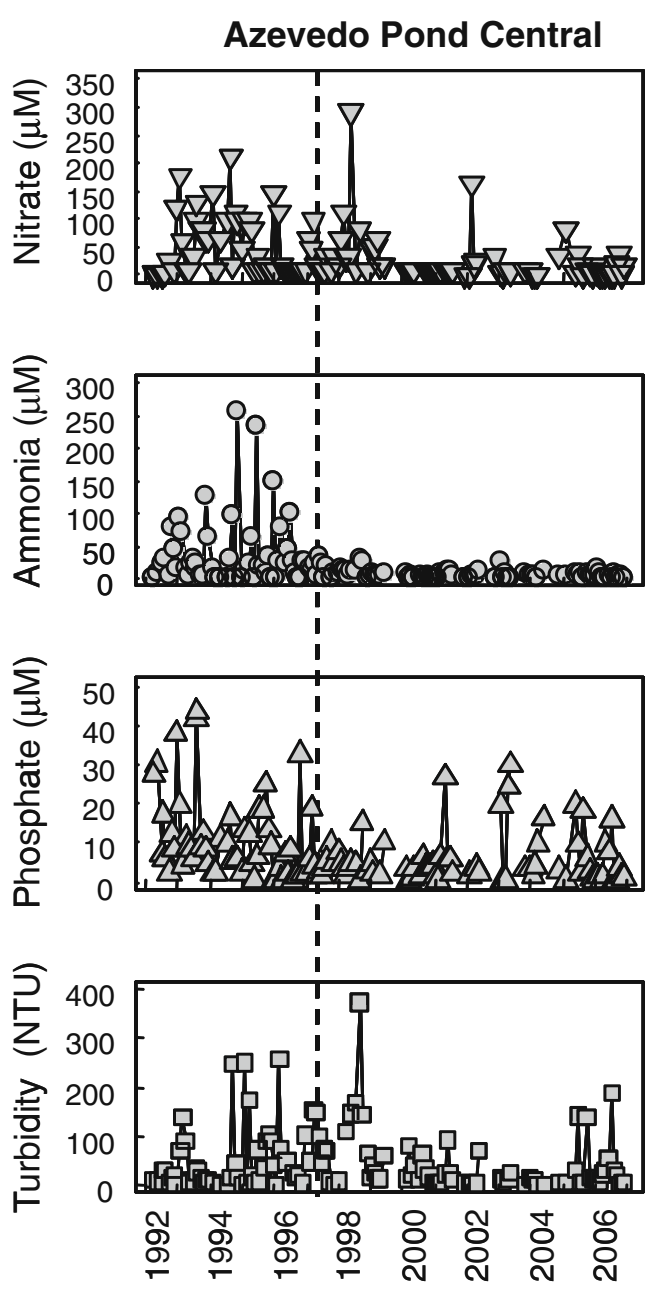

parameters with statistically significant changes using the ANOVA results for each station without Kirby Park values being subtracted (but with the Kirby Park results presented, so the magnitude of control values can be inspected). These results are presented in Figs. 5 and 8 for each case study, respectively. All parametric analyses were conducted using Systat (v.12) statistical software.

Several multivariate statistical analyses were conducted to understand how water quality as a whole changed before vs. after treatments (restoration and tide gate repairs) at the different sites. This included nonmetric multidimensional scaling (nMDS) analyses, analyses of similarities (ANOSIM), and similarity percentages (SIMPER) analyses, all generated using the software program Primer v.6 (Clarke and Gorley 2006). All data were normalized prior to multivariate analyses, so that variance was similar. Euclidean distance similarity matrices were used to create nMDS ordination plots, as recommended for water quality data (Clarke and Gorley 2006). Thus, all simultaneously measured water quality parameters were used together to identify overall signatures of water quality change. The nMDS ordination plots provide a visual 2D representation of similarity between groups. These results are tabulated with the parametric results at the bottom of Tables 2 and 3. ANOSIM is used to statistically test if groups (in this case, annual averages of water quality parameters from years before vs. after treatment) are significantly different. The pair-wise $R$ statistic indicates how much dissimilarity there is between before vs. after treatments at each site for each time period. The SIMPER analyses determine which water quality parameters are driving dissimilarity between groups (Clarke 1993).

\section{Results}

\section{Restoration Acreage Calculations}

Watershed size and weighted average distance from restoration calculations from the GIS analyses are tabulated with respect to each water quality monitoring station, along with relevant history regarding land and flood-control management changes pertinent for each site (Table 1; 
Table 2 Statistical results for Azevedo Pond sites

\begin{tabular}{|c|c|c|c|c|}
\hline \multirow{2}{*}{$\begin{array}{l}\text { Before vs. after restoration } \\
\text { BACI parameters }\end{array}$} & \multicolumn{4}{|l|}{ Station } \\
\hline & $\mathrm{APC}$ & APN & APS & $\mathrm{KP}$ (control) \\
\hline \multicolumn{5}{|l|}{ Salinity } \\
\hline \multicolumn{5}{|l|}{ Temperature } \\
\hline $\mathrm{pH}$ & $* \downarrow$ & & & \\
\hline \multicolumn{5}{|l|}{ Dissolved $\mathrm{O}_{2}$} \\
\hline Turbidity & $* \downarrow$ & & & \\
\hline $\mathrm{NO}_{3}$ & $* \downarrow(-44 \%)$ & $* \downarrow(-61 \%)$ & & \\
\hline $\mathrm{NH}_{3}$ & $* * * \downarrow(-81 \%)$ & & $* \downarrow(-55 \%)$ & \\
\hline $\mathrm{PO}_{4}$ & $* \downarrow(-47 \%)$ & & $* * \downarrow(-47 \%)$ & \\
\hline ANOSIM global $R$ statistic & $0.53^{* *}$ & 0.05 & $0.53 * *$ & 0.09 \\
\hline SIMPER average distance ${ }^{2}$ & 16.16 & 4.61 & 20.53 & 2.57 \\
\hline
\end{tabular}

Statistical results for the Azevedo Pond sites before (1992-1996) and after (1997-2006) restoration. Univariate results are given in the top portion of the table for each parameter, while multivariate results are listed at the bottom. SIMPER results report average squared Euclidean distance between annual averages before vs. after restoration, tracking the magnitude of difference between these time periods for each station. Only significant results are listed. Percentages indicate the decrease in after restoration nutrient concentrations as a percentage of before restoration nutrient concentrations. ${ }^{*} p<0.05 ; * * p<0.005 ; * * * p<0.00005$ (associated BACI and ANOSIM)

Fig. 3). GIS analyses were performed for each of the Azevedo Ponds, as well as for the nested watersheds that drain into the Porter Marsh stations CC and HLE (Fig. 3). Documentation of the restoration projects at Elkhorn Slough indicates that the restoration efforts impacting the Azevedo Ponds were complete by 1997, while for Porter Marsh restoration was ongoing, with this phase being complete by 2002 (Silberstein et al. 1997a, b; M. Silberstein, personal communication). New restoration projects are ongoing at the Elkhorn Slough beyond the timeframe of this paper, so while this study strives to document patterns of change in early restoration efforts, it will also provide a solid baseline against which to assess future changes in water quality, related to restoring natural habitats and functions. Note that the size of the watershed draining into Porter Marsh is two to three orders of magnitude larger than the watersheds for each of the Azevedo Ponds (Fig. 1; Table 1). In addition, an order of magnitude more land was restored within the Porter Marsh watershed (Fig. 3; Table 1). However, when acreage restored as a percent of subwatershed acreage is calculated for each station considered here, roughly $40 \%$ of the subwatershed was restored for APC and APN, while only $1 \%$ of the Porter watershed was restored.

\section{Azevedo Pond Sites}

\section{Univariate Water Quality Analyses}

Univariate BACI analyses performed on annually averaged data for each of the three Azevedo Pond sites revealed changes in different water quality parameters between the before and after restoration periods of time (Table 2). APC showed the most change, with statistically significant decreases in the concentrations of $\mathrm{NO}_{3}, \mathrm{NH}_{3}$, $\mathrm{PO}_{4}$, and turbidity in the postrestoration time period. Of these parameters, $\mathrm{NH}_{3}$ had the most statistically significant change in concentration following restoration (Table 2). It was also the nutrient that showed the most obvious change in concentration in the monthly time series data (Fig. 4). APS showed statistically significant decreases in two of the three nutrients measured. While there was an increase in turbidity at APS, it was not statistically significant in BACI design. Inspection of the data and field records from 2005 and 2006 indicates that this increase in turbidity at APS may be linked to increased chlorophyll $a$ concentrations from phytoplankton in this pond. We began measuring in situ chlorophyll $a$ concentrations at this station in 2005 as well as making periodic laboratory chlorophyll $a$ analyses from grab samples. These data together with field notes and inspection of digital photographs taken at each sampling event seem to indicate a progressive increase in macroalgae and chlorophyll $a$ concentration in recent years at APS and other locations in the slough. However, we could not include chlorophyll as a water quality parameter in our statistical analyses as we have no before restoration data records. Only $\mathrm{NO}_{3}$ showed a statistically significant change in concentration at APN. Of the nutrients that were found to change significantly at these three pond sites, all of them decreased postrestoration (Table 2).

While parametric tests were performed on all water quality parameters, the before and after restoration ANOVA 
Table 3 Statistical results for the Porter Marsh sites. Time periods are as follows: before tide gates repaired (1990-1995), after tide gates repaired and before restoration (1996-2001), and after restoration (2002-2006). Univariate results are given in the top portion of the table for each parameter, while multivariate results are listed at the bottom. The pair-wise $R$ statistic measures the degree of dissimilarity between treatment periods for each separate test. The global $R$ statistic at the bottom of the table indicates overall site differences considering all periods together. Only significant results are listed. Percentages indicate the change in after-restoration or tide gate repair nutrient concentrations as a percentage of before-restoration or tide gate repair nutrient concentrations. $* p<0.05$; ${ }^{* *} p<0.005 ; * * * p<0.0005$; $* * * * p<0.00005$ (associated BACI and ANOSIM)

\begin{tabular}{|c|c|c|c|c|}
\hline \multirow[t]{2}{*}{ BACI parameters } & \multicolumn{4}{|l|}{ Station } \\
\hline & $\mathrm{CC}$ & HLE & HLW & $\mathrm{KP}$ (control) \\
\hline \multicolumn{5}{|l|}{ Before vs. after restoration } \\
\hline \multicolumn{5}{|l|}{ Salinity } \\
\hline \multicolumn{5}{|l|}{ Temperature } \\
\hline \multicolumn{5}{|l|}{$\mathrm{pH}$} \\
\hline \multicolumn{5}{|l|}{ Dissolved $\mathrm{O}_{2}$} \\
\hline \multicolumn{5}{|l|}{ Turbidity } \\
\hline \multicolumn{2}{|l|}{$\mathrm{NO}_{3}$} & \multicolumn{3}{|l|}{$* \downarrow(-75 \%)$} \\
\hline \multicolumn{5}{|l|}{$\mathrm{NH}_{3}$} \\
\hline $\mathrm{PO}_{4}$ & \multicolumn{4}{|l|}{$* \downarrow(-64 \%)$} \\
\hline ANOSIM pair-wise $R$ statistic & $0.30^{*}$ & $0.34 *$ & $0.59^{* *}$ & 0.09 \\
\hline SIMPER average distance ${ }^{2}$ & 15.66 & 11.19 & 7.00 & 1.99 \\
\hline \multicolumn{5}{|l|}{ Before vs. after tide gate repair } \\
\hline Salinity & $* * * * \downarrow$ & $* * * \downarrow$ & $* \downarrow$ & \\
\hline \multicolumn{5}{|l|}{ Temperature } \\
\hline $\mathrm{PH}$ & & $* \uparrow$ & & \\
\hline \multicolumn{2}{|l|}{ Dissolved $\mathrm{O}_{2}$} & $* \uparrow$ & & \\
\hline Turbidity & $* \uparrow$ & & & \\
\hline \multicolumn{2}{|l|}{$\mathrm{NO}_{3}$} & $* \uparrow(+84 \%)$ & $* \uparrow(+83 \%)$ & \\
\hline $\mathrm{NH}_{3}$ & \multicolumn{4}{|l|}{$* \uparrow(+41 \%)$} \\
\hline $\mathrm{PO}_{4}$ & $* * \uparrow(+69 \%)$ & \multicolumn{3}{|l|}{$* \uparrow(+59 \%)$} \\
\hline ANOSIM pair-wise $R$ statistic & $0.68 * *$ & $0.82 * *$ & $0.92 * *$ & $0.58 *$ \\
\hline SIMPER average distance ${ }^{2}$ & 24.62 & 21.51 & 10.60 & 3.55 \\
\hline \multicolumn{5}{|c|}{ Before tide gate repair vs. after restoration } \\
\hline Salinity & $* * * * \downarrow$ & \multicolumn{3}{|l|}{$* \downarrow$} \\
\hline Temperature & $* \downarrow$ & & & \\
\hline \multicolumn{5}{|l|}{$\mathrm{pH}$} \\
\hline Dissolved $\mathrm{O}_{2}$ & & $* \uparrow$ & & \\
\hline \multicolumn{5}{|l|}{ Turbidity } \\
\hline \multicolumn{5}{|l|}{$\mathrm{NO}_{3}$} \\
\hline $\mathrm{NH}_{3}$ & $* \uparrow(+39 \%)$ & & & \\
\hline \multicolumn{5}{|l|}{$\mathrm{PO}_{4}$} \\
\hline ANOSIM pair-wise $R$ statistic & $0.33^{*}$ & $0.77 * *$ & $0.31 *$ & 0.06 \\
\hline SIMPER average distance ${ }^{2}$ & 16.04 & 13.04 & 4.51 & 1.83 \\
\hline ANOSIM global $R$ statistic & $0.44 * *$ & $0.67^{* *}$ & $0.61 * *$ & $0.21 *$ \\
\hline
\end{tabular}

means and standard errors for measured concentrations are presented here for the water quality parameters of interest that changed significantly (Fig. 5). The ANOVA performed on the Kirby Park data (control site) revealed no statistically significant changes in the pre- and postrestoration time periods for any of the parameters measured (Fig. 5; Table 2). Of the three ponds where restoration was conducted, APS had the highest $\mathrm{PO}_{4}$ and $\mathrm{NO}_{3}$ loadings before restoration, while APC had the highest $\mathrm{NH}_{3}$ concentration before restoration. Of the three nutrients measured, $\mathrm{NH}_{3}$ seems to have leveled off the most to roughly similar concentrations between ponds, postrestoration. At APC, the average concentration of $\mathrm{NH}_{3}$ in the postrestoration years decreased by $81 \%$ of the average concentration in prerestoration years $(36.0 \pm 4.4 \mu \mathrm{M} \mathrm{NH}$ down to $7.0 \pm 0.9 \mu \mathrm{M} \mathrm{NH} \mathrm{NH}_{3}$ ). The $\mathrm{NO}_{3}$ concentration dropped $44 \%$ and the $\mathrm{PO}_{4}$ dropped by $47 \%$ of prerestoration levels at this site. At APS, the $\mathrm{NH}_{3}$ concentration dropped by $55 \%$ of prerestoration levels and the $\mathrm{PO}_{4}$ decreased by $47 \%$ of prerestoration levels (Table 2).

\section{Multivariate Results}

The ANOSIM analyses found two of the three ponds (APC and APS) to be significantly dissimilar in water quality before vs. after restoration (bottom of Table 2). Note that $R$ 
Fig. 5 Univariate analysis of variance plots for the water quality parameters that changed significantly at three Azevedo Pond Stations and Kirby Park (control station) after restoration. Untransformed averaged concentrations measured at each station for the time periods before and after restoration are presented here with the standard error, while statistics were performed on log-transformed values with Kirby Park concentrations subtracted first
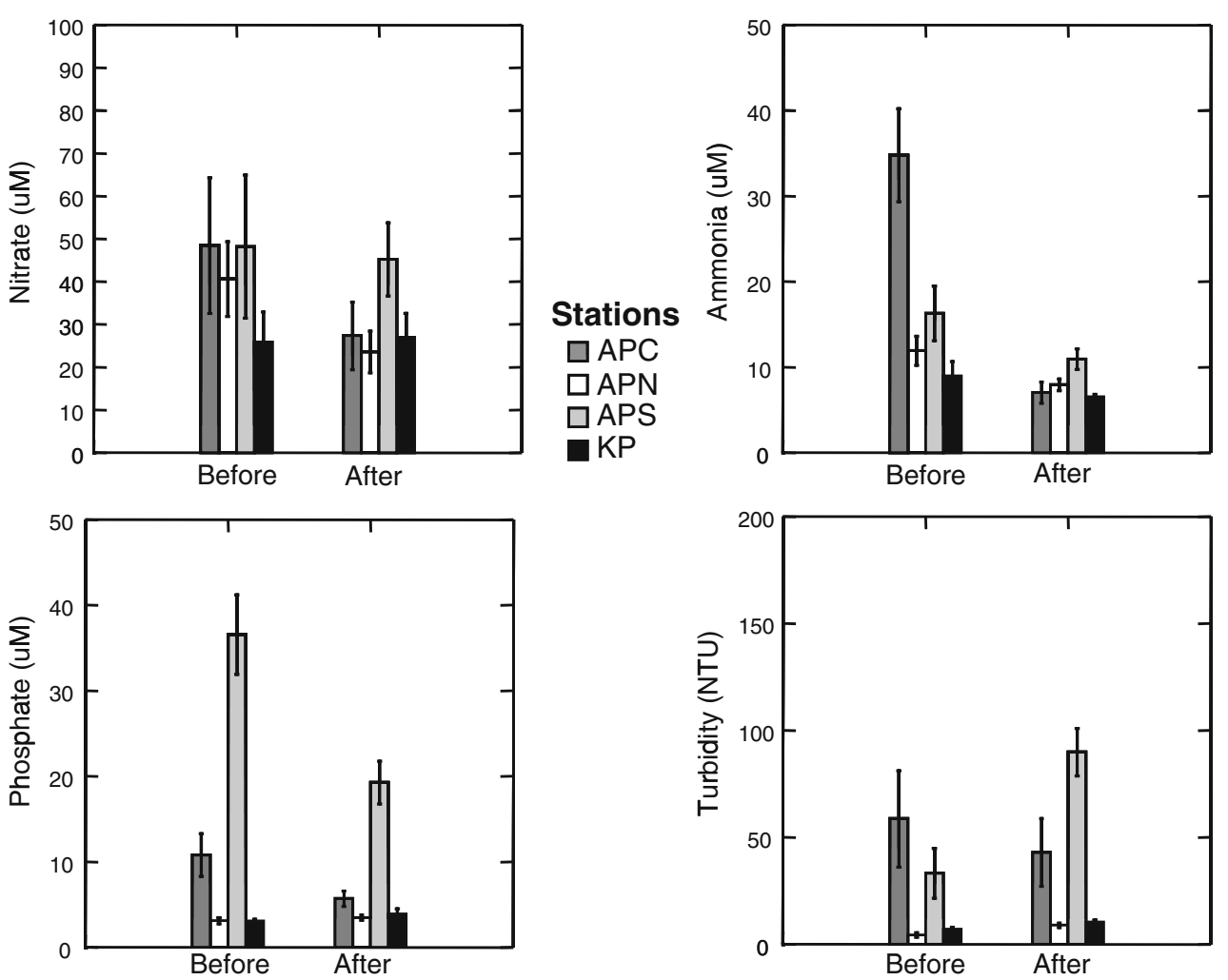

statistics above 0.2 can be regarded as significant (Clarke 1993). The $p$ values associated with the $R$ statistics are also summarized in Table 2. In contrast, APN and KP did not show significant dissimilarity in the multivariate ANOSIM test results (Table 2). These results are displayed visually in the multidimensional scaling (nMDS) plots presented in Fig. 6. Here, we see a clear separation of the before vs. after annual averages in the APC data. Note that 1998 appears to be somewhat of an outlier year, possibly because it was the only major El Nino year during the time period of these data. We see this in the 1998 multivariate data at APC and to a lesser degree at APS, possibly because these are such small ponds (Fig. 6). The excess rainfall would have a correspondingly larger impact on these sites due to dilution and transport effects and could have skewed various water quality data in this year away from the tendency of the other postrestoration years portrayed in the multivariate data. Regardless, there is no overlap of before and after restoration data points for APC. The nMDS plot for APS data also show a clear separation between before and after annual averages, although the data appear less tightly clustered. We see more overlap in the before vs. after restoration data for APN, reflecting the nonsignificant ANOSIM result for this site. There is also more overlap of before and after annual averages for KP, not significant in the ANOSIM analysis (Fig. 6). All nMDS analyses have a $2 \mathrm{D}$ stress of 0.12 or less. A cutoff of stress values below
0.20 is generally accepted for analyzing ordination patterns for multivariate data (Clarke 1993).

The above patterns detected by ANOSIM (significant differences in water quality before vs. after restoration for APC and APS, but not for APN or KP) were corroborated by examination of the squared distances between before vs. after groups using SIMPER. The average squared distance (a measure of similarity) was high for before vs. after groups for APC and APS, but low for APN and KP (Table 2). We also employed the SIMPER function of Primer (Clarke and Gorley 2006) to determine which individual water quality parameters contributed most to the dissimilarity between before vs. after periods at the two sites with significant differences. The SIMPER results indicate that in general, nutrient and turbidity changes are driving water quality differences before vs. after restoration at APC and APS. $\mathrm{NH}_{3}$ and turbidity were the top two contributors to dissimilarity in the before vs. after restoration periods at APC while $\mathrm{PO}_{4}$ and turbidity were the top two contributors for APS.

\section{Porter Marsh Sites}

\section{Univariate Results: Before and After Restoration}

Univariate BACI tests revealed that only one parameter at two Porter Marsh sites showed significant changes in 

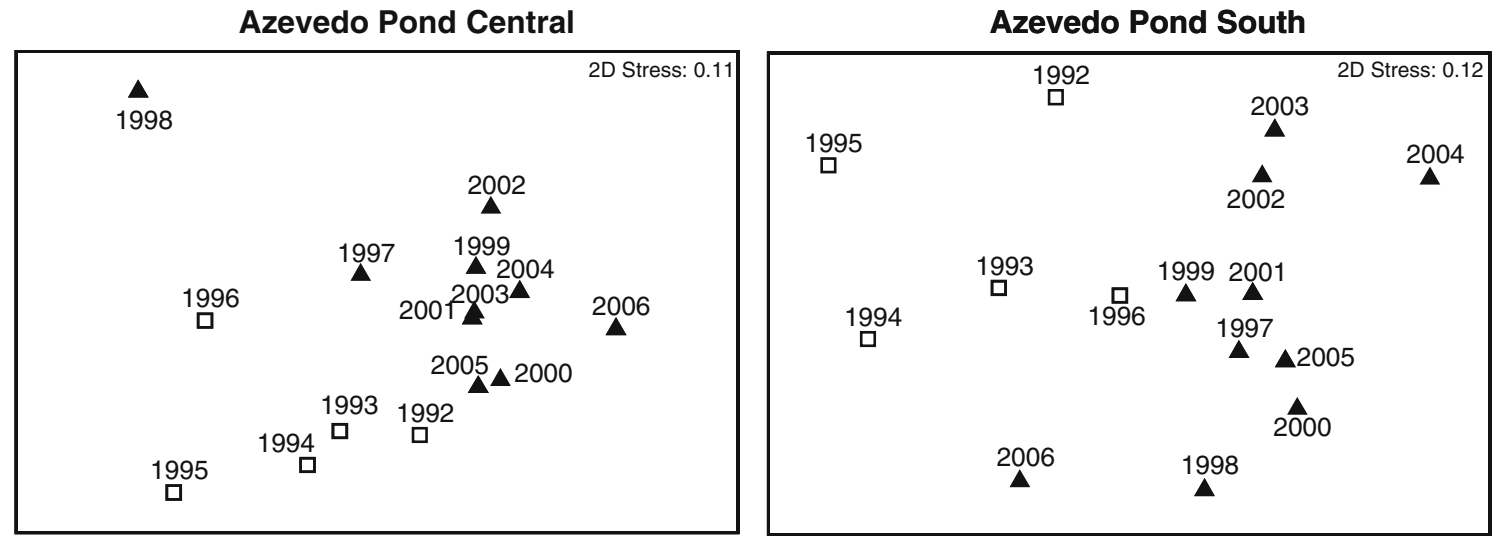

Azevedo Pond North

Kirby Park

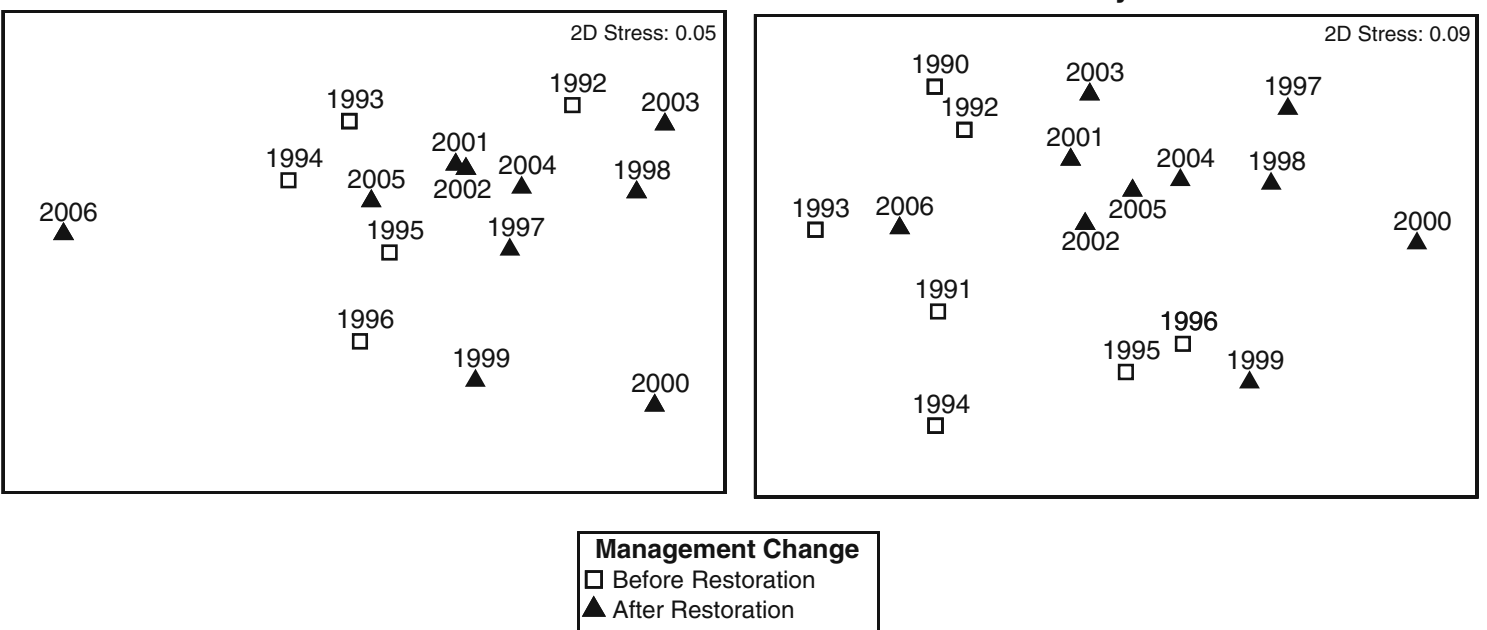

Fig. 6 nMDS ordinations of annual water quality averages before and after restoration at the Azevedo Ponds and at Kirby Park station. All water quality parameters measured were included in the multivariate analysis

concentration before and after restoration was complete (Table 3; Fig. 7). $\mathrm{PO}_{4}$ decreased significantly at $\mathrm{CC}$ while $\mathrm{NO}_{3}$ decreased at HLE, relative to any changes that happened at KP. None of the water quality parameters measured showed significant changes in BACI analysis at HLW, located on the more marine-influenced west side of the Porter Marsh tide gates (Table 3). The before and after restoration ANOVA means and standard errors for measured concentrations are presented here for the nutrient and turbidity data (Fig. 8). There is no significant difference in the Kirby Park data (control site) before and after restoration, for the parameters tested (Table 3; Fig. 8). There is an absolute decrease in $\mathrm{NO}_{3}$ at CC, HLE, and HLW but only HLE $\mathrm{NO}_{3}$ decreases significantly in the BACI statistical analyses (Fig. 8; Table 3). Similarly, there is an absolute decrease in $\mathrm{NH}_{3}$ and turbidity at HLE and HLW, but this not significantly detected in BACI design. There is no significant change in salinity, temperature, or dissolved oxygen in either BACI or ANOVA design before and after restoration in the Porter Marsh watershed (Table 3). For $\mathrm{NH}_{3}, \mathrm{PO}_{4}$, and turbidity, there is a progression from higher to lower concentrations in the flow down the Slough from CC to HLE to HLW to KP, during each of the three time periods examined (Fig. 8). The exception to this pattern is that $\mathrm{NO}_{3}$ concentrations at $\mathrm{CC}$ are lower than at HLE for all time periods and $\mathrm{PO}_{4}$ concentrations are lower at CC than at HLE for only the postrestoration time period.

\section{Univariate Results: Before and After Tide Gate Repairs}

Univariate BACI tests performed on the annual averages before and after the Porter Marsh tide gates were repaired show a significant change in seven out of the eight parameters measured at one or more of the Porter stations (note that the "after tide gates repaired" time period is the same as the "before restoration" time period; Tables 1 and 3). Of the parameters measured, salinity showed the most significant change, decreasing at all three Porter stations after tide gates were repaired. The impact of tide gate repairs on salinity is graphically evident in the time series data from Carneros 
Fig. 7 Time series nutrient and salinity data from Carneros Creek (Porter Marsh) and Kirby Park (control station). Tide gates were repaired at Porter Marsh in 1996, and restoration efforts in this subwatershed amounting to 220 acres were complete in 2002. These two important years are indicated by the pairs of dashed vertical lines

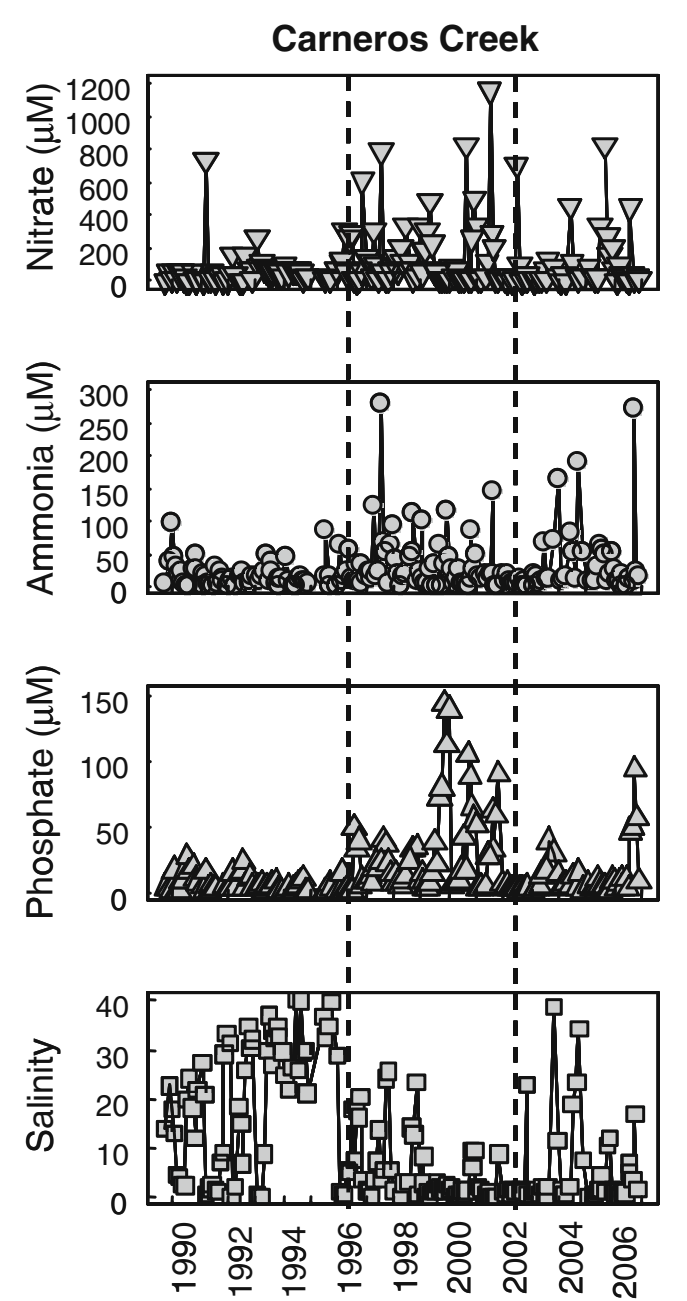

Creek (see CC salinity panel before and after first dashed vertical line; Fig. 7). All the other tests that revealed significant results in BACI design showed increases posttide gate repair. The $\mathrm{CC}$ and HLE stations showed the most changes, with two of the three nutrients and at least one other water quality parameter increasing postrepair. Figure 8 shows graphically that there was a marked increase in nutrient concentrations and turbidity after the tide gates were repaired, especially at $\mathrm{CC}$ and $\mathrm{HLE}$. At $\mathrm{CC}, \mathrm{NH}_{3}$ concentrations nearly doubled after tide gates were repaired, while $\mathrm{PO}_{4}$ concentrations increased by almost 70\% (Fig. 8). At HLE, both $\mathrm{NO}_{3}$ and $\mathrm{PO}_{4}$ concentrations more than doubled from pretide gate repair concentrations (Table 3; Fig. 8). $\mathrm{NO}_{3}$ concentrations also increased following tide gate repair at HLW to a similar extent as HLE (Fig. 8; Table 3).

\section{Multivariate Results}

The ANOSIM analyses reveal that all three Porter Marsh sites were significantly different before vs. after restoration, with a pair-wise $R$ statistic of at least 0.30 (bottom of Table 3 ). In contrast, KP was not significantly dissimilar with a pair-wise $R$ statistic of 0.09 . There is a progressive shortening of the average squared distance calculated for each site, with $\mathrm{CC}$ having the largest distances between points and KP having the smallest. Significant dissimilarity was indicated at all four stations in the ANOSIM analyses before vs. after tide gate repair, with higher $p$ values, $R$ statistics, and average squared distances at all sites (Table 3). When before tide gate repair annual averages are compared with after restoration annual averages using ANOSIM, we again find significant dissimilarity at the Porter Marsh sites but not at KP (Table 3). Statistical significance and average squared distance values are generally intermediate between those seen for the restoration test and the tide gate repair tests. The progression from more dissimilarity at $\mathrm{CC}$ to the least dissimilarity at $\mathrm{KP}$ is maintained during all three time period comparisons made.

When these data are presented in nMDS plots, there emerges a general pattern of the before tide gate repair data points plotting to the far right of the figures, the after tide gates were repaired but before restoration data points plotting to the far left of the figures, and the after restoration data points plotting in between (Fig. 9). All nMDS ordinations have a 2D 
Fig. 8 Univariate analysis of variance plots for nutrient and turbidity concentrations at Porter Marsh Stations and Kirby Park (control station) during the three time periods considered: before tide gates repaired, before restoration but after tide gates repaired, and after restoration. Untransformed averaged concentrations measured at each station for each time period are presented here with the standard error, while statistics were performed on log-transformed values with Kirby Park concentrations subtracted first
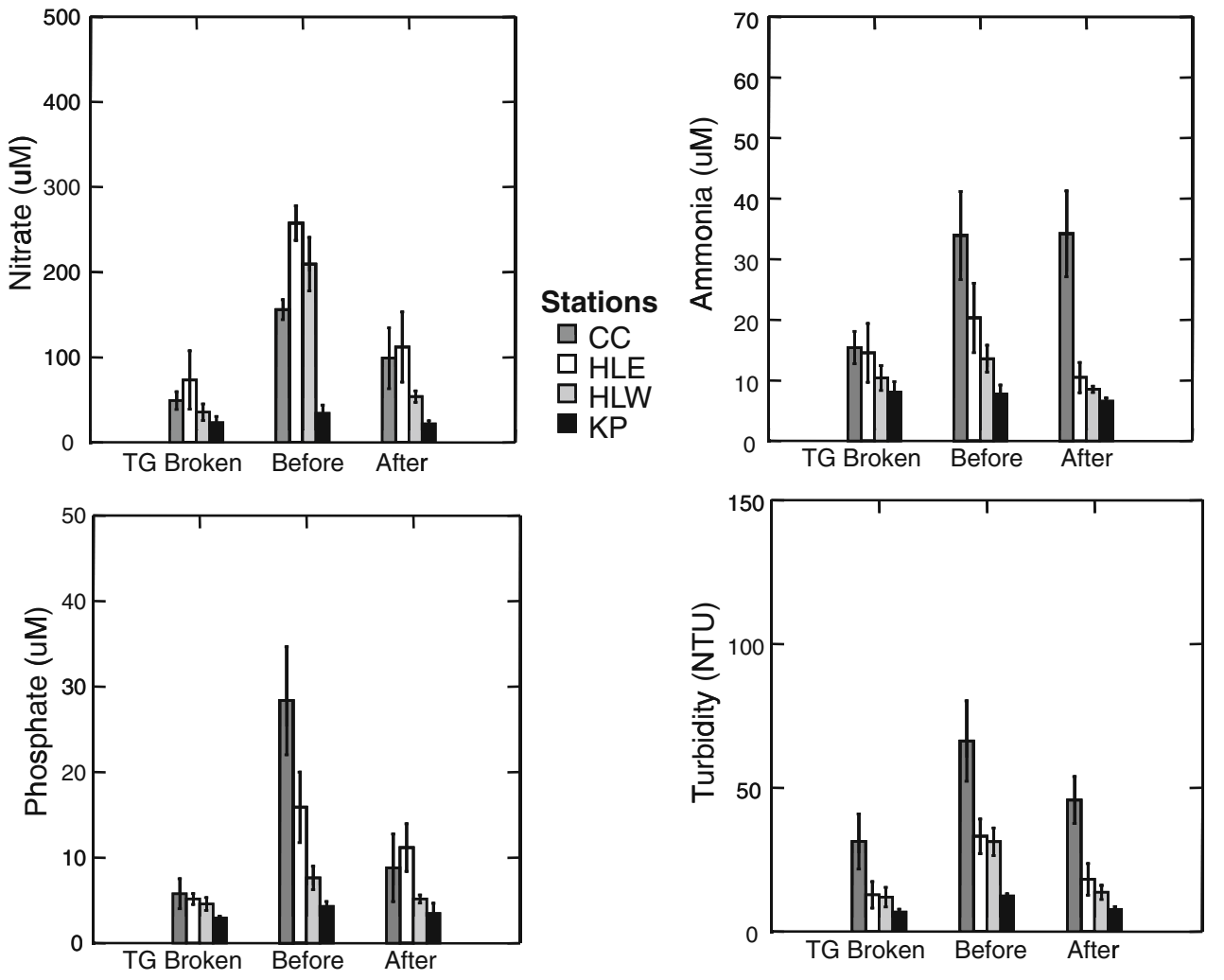

stress of 0.11 or less. Of the three time periods examined, the middle time period (after tide gates were repaired and before restoration) generally has the most separation of data points (reflected in the largest average squared distance values for each site; Table 3). The HLE before tide gate repair annual averages are most clustered as a group. The most overlap between groups is seen at KP (Fig. 9).

\section{Discussion}

\section{Signatures of Restoration in the Water Quality Data}

Coastal managers rely on water quality data to determine whether land-use changes intended to improve wetland health were successful; however, evaluating the success of such programs is not always straightforward (Ruiz-Jaen and Aide 2005). We found that the monthly water quality data set at Elkhorn Slough has enough resolution to capture decadal scale changes in water quality that can reasonably be tied to restoration efforts in the Azevedo and Porter Marsh watersheds considered here. The Azevedo water quality indicates that the installation of buffer strips and the conversion of upper watershed fields to low tillage crops had their intended effect, with nutrients decreasing at all three ponds and turbidity also decreasing at APC (Rein et al. 2007). APC showed the largest change in water quality of the three ponds, presumably responding to the significant $(37 \%)$ restoration of
APC watershed acreage (Table 1). While only $5 \%$ of the watershed acreage for APS was restored, more than half of the land restored was immediately adjacent to the perimeter of this pond, suggesting proximity of restoration to be an important factor on impacting water quality. Postrestoration nutrient concentrations at both APC and APS average a 50\% reduction from prerestoration concentrations (average of three measured nutrients with statistically significant changes in BACI design at these sites; Table 2). The history of these sites suggests that restoration was the significant change occurring in the subwatershed that could affect water quality for APC and APS over the time period assessed. The BACI design statistics should effectively remove factors such as weather from the statistical noise (Stewart-Oaten et al. 1986). Based on these findings and histories, we interpret these changes in water quality to be coupled to land processes and to be signatures of restoration in the APC and APS subwatersheds.

The BACI univariate analyses for the Porter Marsh data also showed decreased nutrient concentrations by roughly $70 \%$ of prerestoration levels (average of statistically significant results for phosphate at Carneros Creek and nitrate at Hudsons Landing East; Tables 2 and 3). This was higher than the average of $50 \%$ decrease seen in nutrient concentrations postrestoration at APC and APS. However, the impact of restoration at the Porter Marsh sites appears to be muted, affecting fewer parameters at fewer stations. When all nutrients that decreased at Porter Marsh as indicated in the 
Fig. 9 nMDS ordinations of annual water quality averages for three management periods at the Porter Marsh and at Kirby Park Stations (before tide gates were repaired, after tide gate repairs but before restoration, and after restoration). All water quality parameters measured were included in the multivariate analysis
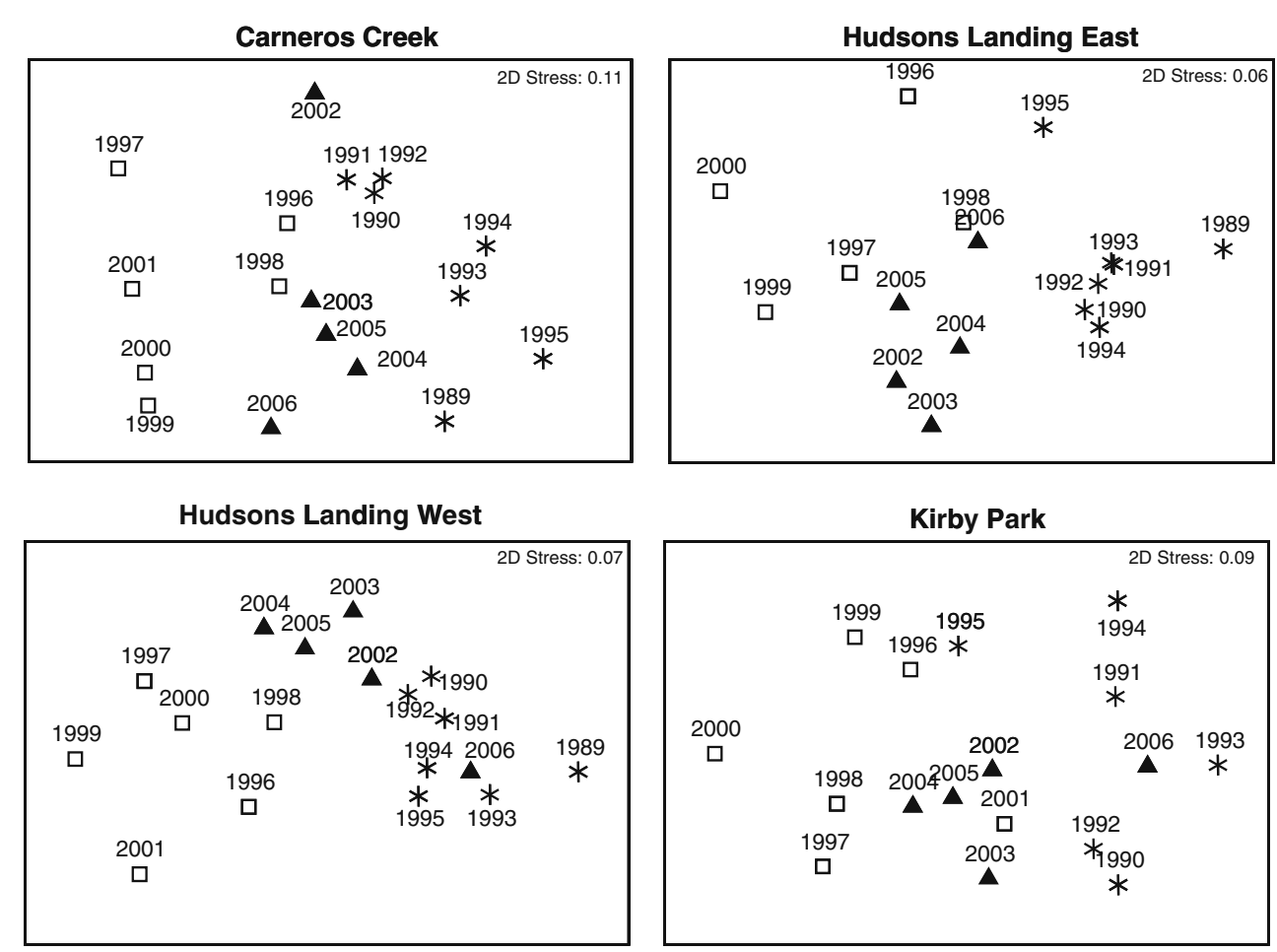

Kirby Park

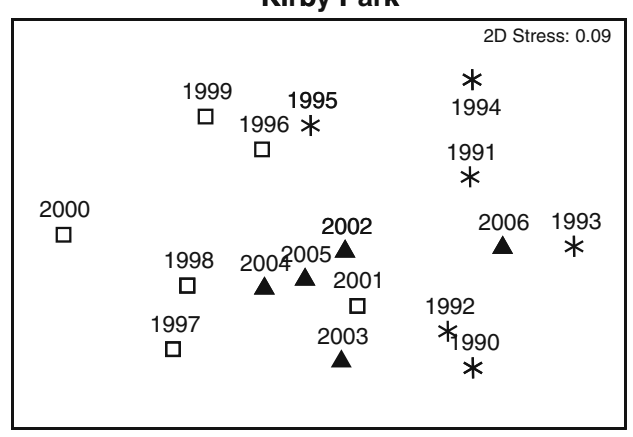

Management Change

$\square$ Before Restoration

After Restoration

*Before Tide Gate Repair
ANOVA results are included, the overall nutrient concentration decrease was roughly $40 \%$ of prerestoration concentrations (Fig. 8). The multivariate ANOSIM results still show significant dissimilarity before and after restoration, but the differences driving this dissimilarity when examined one parameter at a time were not strong enough to show up in the BACI analyses (Table 3).

Other studies on nutrient loads to the Porter Marsh system indicate that Watsonville Creek carries some of the highest nitrate and phosphate concentrations into the Slough (Fig. 1; Los Huertos et al. 2001). This particular creek feeds into the slough above Hudsons Landing but below the Carneros Creek monitoring station and thus could explain the different signals in water quality change seen at these stations. Given that the phosphate levels coming from Watsonville Creek are so high, it is reasonable that the decrease in $\mathrm{PO}_{4}$ at Carneros Creek is inundated when carried downstream to Hudsons Landing. The ANOVA data corroborate this interpretation, showing a clear pattern of progressive decreases in nutrient concentration down gradient for ammonia before and after restoration, but not for phosphate or nitrate at CC (higher at HLE than CC; Fig. 8). The BACI results, however, reveal a significant decrease in $\mathrm{NO}_{3}$ at HLE and not at $\mathrm{CC}$ (Table 3). The ANOVA concentration data show that in fact $\mathrm{NO}_{3}$ concentrations did decline postrestoration at $\mathrm{CC}$ with no overlap of standard error; however, when the Kirby Park nitrate concentrations are subtracted, this result is no longer significant in BACI design (Fig. 8; Table 3). Based on these observations, we conclude that the significant changes listed in Table 3 for CC and HLE are conservative estimates for restoration impacts on water quality at the Elkhorn Slough.

\section{Benthic Nutrient Fluxes Considered with Respect to Restoration}

Benthic fluxes can play an important role in dissolved nutrient concentrations in shallow water estuarine systems because much of the organic matter generated in the water column gets decomposed and regenerated in the sediments (Graf 1992; Jorgensen and Richardson 1996). Our assertion that the decreases in nutrient concentrations over time at APC, APS, and to a lesser extent at CC and HLE are in fact signatures of restoration is further supported by examination of the magnitude of documented benthic flux estimates for ammonia and nitrate in sediments from Elkhorn Slough. Benthic flux measurements from microcosm studies using Elkhorn Slough sediments from shallow intertidal areas similar to the Azevedo Pond sites averaged a flux of $0.7 \mathrm{mmol} \mathrm{m}^{-2} \mathrm{day}^{-1}$ for ammonia (K. Johnson, unpublished data). Raw concentration data from these experi- 
ments show concentrations increased to $20 \mu \mathrm{M} \mathrm{NH}$ after $6 \mathrm{~h}$, well below the 100-250- $\mu \mathrm{M}$ range of ammonia spikes seen in our prerestoration data set for APC and APS (Fig. 4). Caffrey et al. measured a benthic flux in APS as high as $8.6 \pm 2.9 \mathrm{mmol} \mathrm{NH}_{3} \mathrm{~m}^{-2}$ day $^{-1}$, with concentration peaks at least one order of magnitude smaller than the concentration spikes seen in our data (Caffrey et al. 2002b).

Similar microcosm studies for nitrate have shown net negative benthic fluxes and indicate that the sediments in Elkhorn Slough can act as a sink for nitrate rather than a source. The magnitude of this sink is on the order of -12 to $-2 \mathrm{mmol}$ nitrate $\mathrm{m}^{-2}$ day ${ }^{-1}$ depending on the sedimentary environment ( $\mathrm{K}$. Johnson, personal communication). A similar flux of $-4.43 \pm 2.67 \mathrm{mmol} \mathrm{NO}_{3} \mathrm{~m}^{-2}$ day $^{-1}$ was measured in APS (Caffrey et al. 2002b). While this sedimentary sink for nitrate could be contributing slightly to the decrease in concentrations seen at APC and APN, the magnitude is small and is not enough to be the primary mechanism accounting for the overall decrease seen postrestoration. For dissolved inorganic phosphate (DIP), maximum benthic fluxes measured in APS were $1.08 \pm$ $0.52 \mathrm{mmol} \mathrm{DIP} \mathrm{m}^{-2} \mathrm{day}^{-1}$ and were observed to be negative fluxes in other parts of the slough (Caffrey et al. 2002b). Together these studies indicate that typical benthic fluxes for these three nutrients are too small to account for the decreases in nutrient concentrations seen at the Azevedo Ponds postrestoration and that these concentration changes therefore are most likely coupled to land processes associated with changes in agricultural runoff.

\section{Rainfall Effects on Nutrient Concentrations}

With its Mediterranean climate and three distinct seasons, the Elkhorn Slough gets its rain between the months of October and May with an average annual rainfall of $52 \mathrm{~cm}$ (Caffrey et al. 2002a). Rainfall is, however, extremely variable to the slough on seasonal, annual, and interannual timescales. It has been documented that nitrate concentrations in various parts of the slough are the highest during the rainy season and are associated with pulses of freshwater runoff (Los Huertos et al. 2001; Caffrey et al. 2002a, 2007; Johnson, unpublished data). It has also been speculated that other nutrients follow similar patterns of increasing concentrations with rainfall and runoff events in the slough watershed (Caffrey et al. 2002a).

We explored the relationship between average and cumulative rainfall per year vs. annual average concentrations of the three nutrients considered in the two case studies presented here. Time series data of cumulative rainfall plotted with annually averaged nutrient concentrations measured at the Azevedo Ponds and at the Porter Marsh water quality monitoring stations show that nitrate concentrations loosely follow peaks in the rainfall pattern over the 17 years plotted, with ammonia following next and phosphate having a very muted response. However, when we ran $t$ tests on the rainfall data, we did not find a statistically significant difference in the before vs. after restoration years results for either average rainfall or cumulative rainfall for either the Azevedo or Porter Marsh time periods considered (e.g., cumulative rainfall in before restoration years for Azevedo sites was $16.22 \pm 5.78 \mathrm{in}$./year and cumulative rainfall in after restoration years for Azevedo sites was $15.73 \pm 6.90$ in./year, $p>$ 0.7). Peak rainfall occurred in the El Niño year of 1998, after restoration was complete (32.8 in./year with an average cumulative rainfall of $15.9 \pm 6.3 \mathrm{in}$./year for the years 1990 2006). For the Azevedo sites, since restoration was complete by 1997 , high nutrient concentrations associated with high precipitation during the El Niño event would have contributed to elevating "after restoration" concentrations. It is clear that rainfall is linked to the transport of nutrients into the slough from terrestrial sources; however, it is possible that this is a more critical effect to consider when examining high temporal resolution data (Hewitt et al. 2001). A more thorough discussion of wet vs. drought years effecting Elkhorn Slough water quality at higher temporal resolution can be found in Caffrey et al. (2007). By using annual averages in our comparisons with BACI design, we are eliminating the seasonal component of nitrate dynamics both in our annual calculations and by subtracting Kirby nitrate concentrations, which were responding to the same meteorological forcing (Stewart-Oaten et al. 1986). The BACI design allows us to characterize the differences between the locations that underwent restoration and the control location within both the before and after time periods, so that the added difference due to restoration can be distinguished. Thus, we are confident that the decreasing nutrient concentration signals documented here predominantly reflect changes in source from land-based restoration activities, even while meteorological effects and oceanic sources may tell a more complex story under higher resolution.

Of the three nutrients considered in this study, ammonia and especially phosphate tend to undergo more particle water exchange reactions compared to nitrate (Nedwell et al. 1999). It is likely that this tendency toward a higher fractionation with particulate forms contributes to why the link to rainfall is more attenuated for these nutrients, particularly for phosphate. In addition, this may also contribute to why our signals of ammonia and phosphate decreases following restoration are somewhat stronger than for nitrate, which can have additional significant tidal sources to the slough complicating its biogeochemical cycling (Chapin et al. 2004). For the Azevedo study, where restoration was much more proximal to the water sample locations than for the Porter Marsh study, it appears that decreases in ammonia and phosphate concentrations were more easily tracked in the restoration water quality 
signature than dissolved nitrate concentrations flowing through the system. Ammonia and phosphate are more readily incorporated into soil biogeochemical cycles that ultimately can contribute to increased dissolved nitrate concentrations down gradient (Schlesinger 2001). As erosion is reduced by pulling back agriculture from the high tide mark at these pond locations, it follows that concentrations of particle reactive chemical species such as ammonia and phosphate would also decrease significantly in a direct and measurable fashion.

\section{Scale Effects of Restoration Impacts on Water Quality}

The scale of watershed restoration projects can obviously have a strong effect on the magnitude of water quality shifts in adjacent wetlands (Perry 2008). The most obvious difference between the two case studies presented here is the scale of the watersheds under consideration. The watersheds for the Azevedo Pond monitoring stations are between two and three orders of magnitude smaller than the nested watersheds for the Hudsons Landing and Carneros Creek monitoring stations (Fig. 1). While one to two orders of magnitude more land was restored in the larger Porter Marsh watershed, as a percentage of total watershed acreage, the restoration acreage effecting Porter Marsh was only 1\% (Table 1; Fig. 3). Given the wide range of farming practices and increasing urbanization in the Elkhorn Slough watershed, any decreases in nutrient or sediment runoff resulting from the $1 \%$ restoration acreage considered here could easily be overridden by increased nonpoint source runoff of nutrients and sediments from the other $99 \%$ of the watershed. As a result, the statistically significant results for Porter Marsh need to be evaluated with considerably more caution than the significant changes measured at the Azevedo Ponds in order to determine what may be driving these observed decreases.

Another important distinction between the two case studies besides watershed size is the proximity of the restoration efforts to the actual sample locations used for monitoring water quality. For the Azevedo Ponds, a portion of the restoration within each station's watershed was conducted in the lowest elevation areas directly adjacent to the ponds. Prior to restoration, strawberries could literally be submerged at high tide at APC (Fig. 2). Restoration efforts specifically involved the design of buffer zones, where agriculture was pulled back from the perimeters of the ponds by at least $100 \mathrm{ft}$ and native plants (primarily bunchgrasses) were reintroduced (Fig. 2; Silberstein et al. 1997a). For APS, while only $5 \%$ of the watershed was restored, all of this restoration occurred on the lower slopes of the APS subwatershed, with the created "buffer zone" along the perimeter of the pond comprising roughly $50 \%$ of the total restored acreage. (Fig. 3; Table 1). In contrast, for CC, the average distance to the restored acreage was approximately
$1,440 \mathrm{~m}$, with many restored fields over 2,000 m away. For the Hudsons Landing stations the distances were even farther, with some restored fields over $3,000 \mathrm{~m}$ away (Fig. 3; Table 1).

While the water quality monitoring program was not designed a priori to test a hypothesis such as the effect of distance from sampling location to restoration, the data do suggest that proximal restoration efforts have a much larger impact on water quality than distal restoration efforts. These data also suggest that the design of restored buffer zones adjacent to the Azevedo Pond sites were in fact successful and had a dramatic effect on decreasing nutrient concentrations in APC and APS (nearly 50\% concentration reductions postrestoration for the three nutrients averaged). We see almost as much decrease in nutrient concentrations at APS with $5 \%$ of the watershed restored but this land being on average $162 \mathrm{~m}$ away from the monitoring station, compared to APC with $37 \%$ of the watershed restored but this land being on average $970 \mathrm{~m}$ away from the monitoring station. Although we have only four data points to consider, the relationship between restoration acreage and average nutrient reduction is portrayed using the data for APC, APS, CC, and KP (Fig. 10). The rapid increase at the beginning of the curve suggests that a little restoration goes a long way toward reducing nutrient concentrations and will continue to have a positive, although less drastic, effect as more acreage gets restored. While we have only two case studies to consider here, our results suggest that proximity of restoration to water sample location may in fact be more important than the size of restoration acreage on impacts to water quality, up to a point. The outcome seen at the Azevedo Ponds illustrates that thoughtful planning of restoration efforts based on local topography and drainage

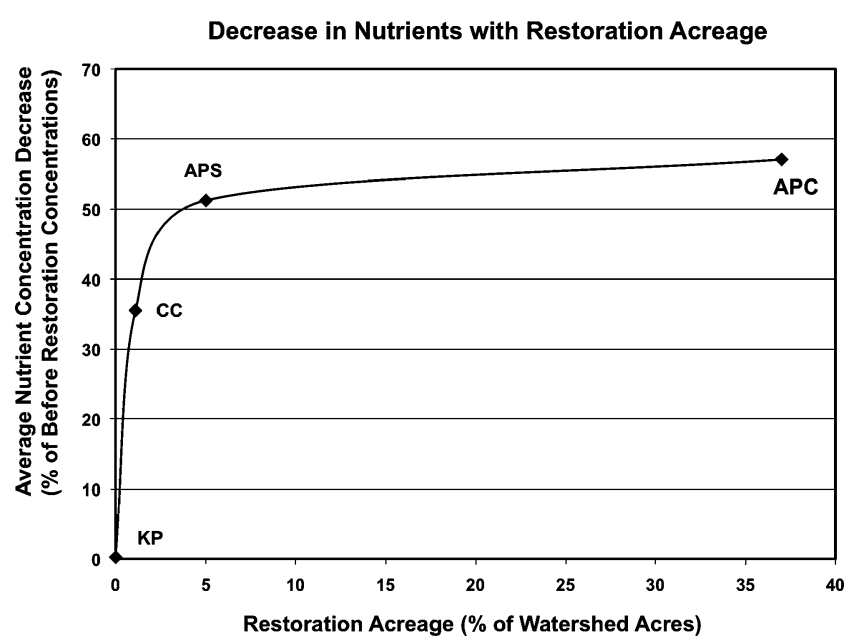

Fig. 10 Relationship between restoration (as percentage of watershed acreage) and average nutrient concentration decrease (as percentage of before restoration concentrations, averaged across all three nutrients) 
patterns that include buffer zones can make substantial differences to nutrient and turbidity loads to local surface water bodies. The outcome seen at the Porter Marsh sites suggests that restoration of even $1 \%$ of a watershed can result in improvements to nutrient loads and water quality.

\section{Signatures of Tide Gate Repairs in the Water Quality Data}

Water control structures can have dramatic effects on estuarine water quality and wetland health (Sanzone and McElroy 1998; Ritter et al. 2008). We detected very strong influences of tide gate management on upstream water quality. To be expected, the most significant statistical results before vs. after tide gate repair were for salinity at Porter Marsh as these structures are designed to control salt water inundation of agricultural lands (CC and HLE; Table 3). Following tide gate repair, Carneros Creek displayed mainly very low salinities, with episodic salinity spikes, probably reflecting leakage of the tide gates to some extent, even after repair (Fig. 7; note strong high salinity signal prior to 1996). The ANOVA shows that all three nutrient concentrations were the lowest during the first time period when the tide gates were broken and before restoration was started (Fig. 8). Consequently, all statistically significant tests in BACI design show increases in concentrations after tide gate repairs (Table 3). The raw data presented for $\mathrm{CC}$ shows that with the exception of one nitrate spike in 1991, all three nutrients have much lower concentrations in the time series when the tide gates were not functioning (Fig. 7). Strong dilution effects occurring while the tide gates were broken thus dramatically improved water quality within the sites, even though no restoration activities occurred to limit nutrient inputs during this period. Indeed, when this dilution effect ended with tide gate repairs, nutrient concentrations again became elevated, indicating no improvement in inputs had occurred. Subsequent restoration in the Porter watershed then brought nutrient concentrations back down to intermediate levels that are still higher than when the tide gates were broken.

It has been observed that daytime oxygen concentrations tend to be higher in more tidally restricted environments in the Elkhorn Slough, presumably driven by nutrient fueled photosynthesis (Ritter et al. 2008). It is possible that the increase in daytime dissolved oxygen detected at HLE following tide gate repairs could be a reflection of tidal exchange restriction. From the perspective of biological communities inhabiting managed wetlands, improvements in water quality resulting from more natural tidal regimes may thus be more significant than those resulting from reduction of nutrient inputs as a part of land-based restoration activities. Examination of a separate database of dissolved oxygen at Elkhorn Slough obtained by sondes deployed to continuously collect in situ measurements has revealed that sites displaying high daytime dissolved oxygen are the same sites that have extended periods of nighttime hypoxia (the Azevedo Ponds are included in this category of sites). Tidal range shows a strong negative correlation with hypoxia, such that sites with very limited tidal range have the greatest duration of hypoxia observed in the estuary (B. Hughes and John Haskins, unpublished data). Since extended hypoxia is well known to have negative impacts on aquatic communities (Diaz and Rosenberg 2008), our study suggests that increased tidal flushing could improve aquatic community health at tidally restricted sites even in the absence of land-use changes. Similar conclusions about the importance of flushing have been made from modeling studies on the effect of drought on estuarine water quality (Attrill and Power 2000). Together these data clearly illustrate that land-based efforts to improve water quality cannot be considered in isolation from management practices that affect the flow of water, regardless of the fact that these operations are often undertaken by different personnel in various organizations. Feedback and communication are important both in implementation of best management practices and in recording the history of management changes over time. Properly performed and professionally monitored citizen-based water quality monitoring datasets can thus powerfully inform both land-use and water control structure operations in an adaptive management framework.

Acknowledgments We thank K. Coale for use of facilities at Moss Landing Marine Labs, K. Contreras for his GIS analyses of agriculture changes over the years of restoration, P. Raimondi for his helpful council regarding statistical analyses, M. Silberstein for his time reviewing the history of the Slough, and E. Van Dyke for the maps presented in Figs. 1 and 3. We are most grateful to the Associate Editor of Estuaries and Coasts, K. Johnson, M. Los Huertos, R. Nuzzi, and an anonymous reviewer for their insight and thoughtful comments on various stages of this manuscript. J. Oakden, J. Oliver, M. Silberstein, and P. Slattery had the foresight to initiate this water quality monitoring program two decades ago, laying the groundwork for analyses such as these. We thank all those individuals that contributed in direct and visionary ways to restoration efforts in the Elkhorn Slough watershed, without which this study would not have been possible. We are deeply grateful to the Monterey County Water Resources Agency (MCWRA) for providing long-term financial support for sample nutrient analyses conducted at the Monterey County Consolidated Chemistry Laboratory and to K. Thomasberg, MCWRA Water Quality Manager, for efforts to continue the partnership in this long-term monitoring program. This manuscript was prepared as part of a PG\&E special projects nonpoint source pollution grant with the Central Coast Regional Water Quality Control Board California Environmental Protection Agency and the Monterey Community Foundation (Grant \# 20040581).

Open Access This article is distributed under the terms of the Creative Commons Attribution Noncommercial License which permits any noncommercial use, distribution, and reproduction in any medium, provided the original author(s) and source are credited. 


\section{References}

A.P.H.A. 2005. Standard methods for the examination of water and wastewater: including bottom sediments and sludges, 21st ed. New York: American Public Health Association.

Attrill, M.J., and M. Power. 2000. Modelling the effect of drought on estuarine water quality. Water Resour 34(5): 1584-1594.

Beck, N.G., and K.W. Bruland. 2000. Diel biogeochemical cycling in a hyperventilating shallow estuarine environment. Estuaries 23: $177-187$.

Beck, N.G., A.T. Fisher, and K.W. Bruland. 2001. Modeling water, heat, and oxygen budgets in a tidally dominated estuarine pond. Mar Ecol Prog Ser 217: 43-58.

Boesch, D. 2006. Scientific requirements for ecosystem-based management in the restoration of Chesapeake Bay and Coastal Louisiana. Ecol Eng 26: 6-26.

Boesch, D., E. Burreson, W. Dennison, E. Houde, M. Kemp, V. Kennedy, R. Newell, K. Paynter, R. Orth, and R. Ulanowicz. 2001. Factors in the decline of coastal ecosystems. Science 293: $1589-1590$.

Breaker, L.C., and W.W. Broenkow. 1994. The circulation of Monterey Bay and related processes. Oceanogr Mar Biol Annu Rev 32: 1-64.

Bricker, S.B., C.G. Clement, D.E. Pirhalla, S.P. Orlandok, and D.F.G. Farrow. 1999. National Estuarine Eutrophication assessment: effects of nutrient enrichment in the Nation's Estuaries. Silver Springs: NOAA, National Ocean Service, Special Projects Office and the National Centers for Coastal Ocean Science.

Bricker, S.B., B. Longstaff, W. Dennison, A. Jones, K. Boicourt, C. Wicks, and J. Woerner. 2008. Effects of nutrient enrichment in the nation's estuaries: A decade of change. Harmful Algae 8: 2132.

Caffrey, J.M., S. Shaw, M. Silberstein, A. De Vogelaere, and M. White. 1997. Water quality monitoring in Elkhorn Slough: A summary of results, 1988-1996. Elkhorn Slough Foundation and Elkhorn Slough National Estuarine Research Reserve report, Watsonville, CA.

Caffrey, J. M., M. Brown, B. Tyler, and M. Silberstein (eds). 2002a. Changes in a California estuary: an ecosystem profile of Elkhorn Slough. Moss Landing: Elkhorn Slough Foundation. 280 p.

Caffrey, J.M., N. Harrington, and B. Ward. 2002b. Biogeochemical processes in a small California estuary. 1. Benthic fluxes and pore water constituents reflect high nutrient freshwater inputs. Mar Ecol Prog Ser 233: 39-53.

Caffrey, J.M., T.P. Chapin, H.W. Jannasch, and J.C. Haskins. 2007. High nutrient pulses, tidal mixing and biological response in a small California estuary: Variability in nutrient concentrations from decadal to hourly time scales. Estuar Coast Shelf Sci 71: 368-380.

Chapin, T.P., J.M. Caffrey, H.W. Jannasch, L.J. Coletti, J.C. Haskins, and K.S. Johnson. 2004. Nitrate sources and sinks in Elkhorn Slough, California: Results from long-term continuous in situ nitrate analyzers. Estuaries 27(5): 882-894.

Clarke, K.R. 1993. Non-parametric multivariate analyses of changes in community structure. Aust $J$ Ecol 18: 117-143.

Clarke, K.R., and R.N. Gorley. 2006. PRIMER v.6: User manual and tutorial. Plymouth: PRIMER E.

Cloern, J.E. 1999. The relative importance of light and nutrient limitation of phytoplankton growth: A simple index of coastal ecosystem sensitivity to nutrient enrichment. Aquat Ecol 33(1): 3-15.

Cloern, J.E. 2001. Our evolving conceptual model of the coastal eutrophication problem. Mar Ecol Prog Ser 210: 223-253.

Cloern, J.E., and A.D. Jassby. 2008. Complex seasonal patterns of primary producers at the land-sea interface. Ecol Lett 11: 1294-1303.

Cohen, J.E. 2003. Human population: The next half century. Science 302: 1172 .

Cohen, J.E., C. Small, A. Mellinger, J. Gallup, and J.D. Sachs. 1997. Estimates of coastal populations. Science 278: 1211.
Conomos, J.T. 1979. Properties and circulation of San Francisco Bay waters. In San Francisco Bay: The urban estuary, ed. J.T. Conomos, A.E. Leviton, and M. Berson, 47-84. San Francisco: Pacific Division of the American Association for the Advancement of Science.

Correll, D.L., T.E. Jordan, and D.E. Weller. 1992. Nutrient flux in a landscape. Effects of coastal land use and terrestrial community mosaic on nutrient transport to coastal waters. Estuaries 15: 431442.

Diaz, R.J., and R. Rosenberg. 2008. Spreading dead zones and consequences for marine ecosystems. Science 321: 926-929.

Duarte, C.M., D.J. Conley, J. Carstensen, and M. Sanchez-Camacho, 2009. Return to Neverland: Shifting baselines affect eutrophication restoration targets. Estuaries and Coasts. 32(1): 29-36.

Elliot, M., D. Burdon, K.L. Hemingway, and S.E. Apitz. 2007. Estuarine, coastal and marine ecosystem restoration: Confusing management and science - a revision of concepts. Estuar Coast Shelf Sci 74: 349-366.

Flegal, A.R. 2000. Dissolved and total trace element data tables. In: San Francisco Estuary Institute Regional Monitoring Program for Trace Substances annual report, Appendix C, pp. A15-A20. Oakland: San Francisco Estuary Institute.

Graf, G. 1992. Benthic-pelagic coupling: A benthic view. Oceanogr Mar Biol Annu Rev 30: 149-190.

Gray, J.S. 1992. Eutrophication in the sea. In Marine eutrophication and population dynamics, eds. Colombo, G., I. Ferrari, V.U. Ceccherelli and R. Rossi, 3-15. Ferrara: Proceedings from the 25th European Marine Biology Symposium.

Hager, S.W., and L.W. Schemel. 1996. Dissolved inorganic nitrogen, phosphorus, and silicon in South San Francisco Bay: Major Factors affecting distribution. In San Francisco Bay: The ecosystem, ed. J.T. Hollibaugh, 217-236. San Francisco: Pacific Division of the American Advancement of Science.

Heip, C. 1995. Eutrophication and zoobenthos dynamics. Ophelia 41: 113-136.

Hewitt, J.E., S.E. Thrush, and V.J. Cummings. 2001. Assessing environmental impacts: Effects of spatial and temporal variability at likely impact sites. Ecol Appl 11(5): 1502-1516.

Howarth, R.W., E.W. Boyer, W.J. Pabich, and J.N. Galloway. 2002. Nitrogen use in the United States from 1961-2000 and potential future trends. Ambio 31: 88-96.

Johnson, K.S., and L.J. Coletti. 2002. In situ ultraviolet spectrophotometry for high resolution and long-term monitoring of nitrate, bromide and bisulfide in the ocean. Deep-Sea Res 49: 12911305.

Jorgensen, B.B., and K. Richardson (eds.). 1996. Eutrophication in coastal marine ecosystems. Coastal and estuarine studies 52. Washington, DC: American Geophysical Union.

Kemp, W.M., and W.R. Boynton. 1984. Spatial and temporal coupling of nutrient inputs to estuarine primary production: The role of particulate transport and decomposition. Bull Mar Sci 35: 522-535.

Largier, J.L., J.T. Hollibaugh, and S.V. Smith. 1997. Seasonally hypersaline estuaries in Mediterranean-climate regions. Estuar Coast Shelf Sci 45: 789-797.

Los Huertos, M., L.E. Gentry, and C. Shennan. 2001. Land use and stream nitrogen concentrations in agricultural watersheds along the central coast of California. The Scientific World Journal 1: 615-622.

Malzone, C. M. 1999. Tidal scour and its relation to erosion and sediment transport in Elkhorn Slough. M.S. thesis, San Jose State University.

McGlathery, K.J., K. Sundback, and I.C. Anderson. 2007. Eutrophication in shallow coastal bays and lagoons: The role of plants in the coastal filter. Mar Ecol Prog Ser 348: 1-18.

Monbet, Y. 1992. Control of phytoplankton biomass in estuaries: A comparative analysis of microtidal and macrotidal estuaries. Estuaries 15: 563-571. 
National Research Council (NRC). 1992. Restoration of aquatic ecosystems-science, technology and public policy, 576. Washington, DC: National Academy.

National Research Council (NRC). 2000. Understanding and reducing the effects of nutrient pollution. Washington, DC: National Academy.

Nedwell, D.B., T.D. Jickells, M. Trimmer, and R. Sanders. 1999. Nutrients in estuaries. In Advances in ecological research: Estuaries, 29, ed. D.B. Nedwell and D.G. Raffaelli, 43-70. San Diego: Academic.

Nichols, F.H., J.E. Cloern, S.N. Luoma, and D.H. Peterson. 1986. The modification of an estuary. Science 231: 567-573.

Nixon, S.W. 1995. Coastal marine eutrophication: A definition, social causes, and future concerns. Ophelia 41: 199-219.

Nixon, S.W. 1998. Enriching the sea to death. Sci Am 9(3): 48-53.

Oberg, J. 2005. Model simulations of conditions suitable for the establishment of Enteromorpha sp. (Chlorophyta) macroalgal mats. Marine Biology Research 1: 97-106.

Paerl, H.W. 2009. Controlling eutrophication along the freshwatermarine continuum: Dual nutrient $(\mathrm{N}$ and $\mathrm{P}$ ) reductions are essential. Estuaries and Coasts 32: 593-601.

Perry, W.B. 2008. Everglades restoration and water quality changes in south Florida. Ecotoxicology 17: 569-578.

Rein, F.A. 1999. Vegetative buffer strips in a Mediterranean climate: Potential for protecting soil and water resources. Ph.D. dissertation, University of California at Santa Cruz.

Rein, F.A., M. Los Huertos, K.D. Holl, and J.H. Langenheim. 2007. Restoring native grasses as vegetative buffers in a coastal California agricultural landscape. Madrono 54(3): 249-257.

Richardson, K. 1996. Carbon flow in the water column. Case study: Southern Kattegat. In Eutrophication in coastal marine ecosystems. Coastal and estuarine studies 52, ed. B.B. Jorgensen and K. Richardson, 179-203. Washington, DC: American Geophysical Union.

Ritter, A.F., K. Wasson, S.I. Lonhart, R.K. Preisler, A. Woolfolk, K.A. Griffith, S. Connors, and K.W. Heinman. 2008. Ecological signatures of anthropogenically altered tidal exchange in estuarine ecosystems. Estuaries and Coasts. 31(3): 554-571.

Ruiz-Jaen, M.C., and T.M. Aide. 2005. Restoration success: How is it being measured? Restor Ecol 13(3): 569-577.

San Francisco Estuary Institute (SFEI). 2008. The 2007 RMP Annual Monitoring Results. The Regional Monitoring Program for Water Quality in the San Francisco Estuary (RMP). SFEI contribution No. 572. San Francisco Estuary Institute, Oakland.

Sanzone, S., and A. McElroy (eds.). 1998. Ecological impacts and evaluation criteria for the use of structures in marsh management. EPA-SAB-EPEC-98-003. Washington, DC: U.S. Environmental Protection Agency.
Schlesinger, W.H. 2001. Biogeochemistry: An analysis of global change. San Diego: Academic.

Silberstein, M., M. Werner, L. Wunderlich, M. Los Huertos, S. Swezey, S. Gliessman, R. Tjeerdema, A. De Vogelaere, and S. Zembsch. 1997a. Report on lands owned by the nature conservancy in Elkhorn Slough: Azevedo Ranch. Moss Landing: Elkhorn Slough Foundation.

Silberstein, M., M. Werner, L. Wunderlich, M. Los Huertos, S. Swezey, S. Gliessman, R. Tjeerdema, A. De Vogelaere, and S. Zembsch. 1997b. Elkhorn Slough Agricultural watershed demonstration program. Moss Landing: Elkhorn Slough Foundation.

Simenstad, C., D. Reed, and M. Ford. 2006. When is restoration not? Incorporating landscape-scale processes to restore self-sustaining ecosystems in coastal wetland restoration. Ecol Eng 26: 27-39.

Small, C., and R.J. Nicholls. 2003. A global analysis of human settlement in coastal zones. J Coastal Res 19(3): 584-599.

Smetacek, V., U. Bathmann, E.M. Nothig, and R. Scharek. 1991. Coastal eutrophication: Causes and consequences. In Ocean margin processes in global change, ed. R.F.C. Mantoura, J.M. Martin, and R. Wollast, 251-279. Chichester: Wiley.

Smith, S.V., and J.T. Hollibaugh. 1997. Annual cycle and interannual variability of ecosystem metabolism in a temperate climate embayment. Ecol Monogr 67: 509-533.

Stewart-Oaten, A., W. Murdoch, and K.R. Parker. 1986. Environmental impact assessment: "Pseudoreplication" in time. Ecology 67 (4): 929-940.

Strickland, J.D.H., and T.R. Parsons. 1972. A practical handbook of seawater analysis. Ottawa: Fisheries Research Board of Canada.

Thebault, J., T.S. Schraga, J.E. Cloern, and E.G. Dunlavey. 2008. Primary production and carrying capacity of former salt ponds after reconnection to San Francisco Bay. Wetlands 28(3): 841-851.

Valiela, I., J. McClellan, J. Hauzwell, B.J. Behr, D. Hersh, and K. Foreman. 1997. Macroalgal blooms in shallow estuaries: Controls and ecophysiological and ecosystem consequences. Limnol Oceanogr 42: 1105-1118.

Valiela, I., M. Geist, J. McClelland, and G. Tomasky. 2000. Nitrogen loading from watersheds to estuaries: Verification of Waquoit Bay Nitrogen Loading Model. Biogeochemistry 49: 277-293.

Van Cleve, F.B., T. Leschine, T. Klinger, and C. Simenstad. 2006. An evaluation of the influence of natural science in regional-scale restoration projects. Environ Manage 37(3): 367-379.

Van Dyke, E., and K. Wasson. 2005. Historical ecology of a central California estuary: 150 years of habitat change. Estuaries 28: 173189.

Vidal, M., C.M. Duarte, and M.C. Sanchez. 1999. Coastal eutrophication research in Europe: Progress and imbalances. Mar Pollut Bull 38: 851-854.

Wong, C.R. 1989. Observations of tides and tidal currents in Elkhorn Slough. M.S. thesis, San Jose State University, San Jose. 